\title{
Removal of Heavy Metals from Water: Technological Advances and Today's Lookout Through Membrane Applications
}

\author{
Pallavi Mahajan-Tatpate ${ }^{1,2}$, Supriya Dhume ${ }^{1}$ and Yogesh Chendake ${ }^{1, *}$ \\ ${ }^{1}$ Department of Chemical Engineering, Bharati Vidyapeeth Deemed to be University, College of Engineering, \\ Pune, India \\ ${ }^{2}$ School of Polymer Engineering, MIT World Peace University, Pune, India
}

\begin{abstract}
Water contamination by heavy metal is a great environmental concern. It leads to many health issues ranging from diarrhea, vomiting to life-threatening diseases like cancer, lung/kidney damage. This also affects soil biota/plant growth. Metal-ions have a tendency of bioaccumulation, hence pose a major issue upon entry in the food-cycle. Their removal from water is necessary before use for human/agricultural applications. Different methods reported for metal-ion separation are conventional methods viz. chemical-precipitation, ion-exchange, adsorption, coagulation, flocculation, flotation, electrochemical possess good separation efficiency, but the generation of a secondary pollutant, recovery issues restrict their applicability. Hence, there is a need of reliable techno-economical, environment-friendly, sustainable separation, recovery method. Membrane-based methods viz. reverse-osmosis, nanofiltration, electrodialysis, ultrafiltration has ability to treat water for heavy metal recovery without chemical contamination. Recovered materials can be recycled/utilized further. Among different membrane-based processes, micellar/polymer enhanced ultrafiltration requires chemical addition and affects purity. Electrodialysis, reverse-osmosis, nanofiltration processes require large energy/operational issues. Hence, simple ultrafiltration with membrane modification is preferable as low-energy requirements. This paper discusses details of conventional/advanced methods for heavy metal separation with the fundamental process, parameters, advantages/limitations.
\end{abstract}

Keywords: Contamination, Effluent, Health / Environmental issues, Methods, Regeneration / Recovery, Separation.

\section{INTRODUCTION}

Pure water is an essential right of human beings and the environment, but progressively it is becoming a rare resource. $70 \%$ of the earth's surface is covered by water, but only $2.5 \%$ is fresh water. Out of this large amount of water is not accessible for humans. Only 1 $\%$ of freshwater can be utilized by humans. This water is becoming highly polluted by human activities and natural calamities. Human activities generate increasing amounts of soluble chemical species which should be removed appropriately before effluent disposal. Among these chemical species, the presence of heavy metals is a major issue affecting the environment adversely. The metals with high density (3.5 to $7 \mathrm{gm} / \mathrm{cm}^{3}$ ) or specific gravity (> 5) or having atomic weight (between 63.5 to 200.6) are known to be heavy metals [1]. They are of special concern due to their high toxicity [2]. These materials are toxic to humans and other living organisms. They possess properties of bioaccumulation, which escalates the issue [3].

Effluent and solid waste disposal from different industries like mining, refinery, leather tanning, textile,

\footnotetext{
"Address correspondence to this author at the Department of Chemical Engineering, Bharati Vidyapeeth Deemed to be University, College of Engineering, Pune, India; Tel: +91 2024107390 Ext. 319;

E-mail: yjchendake@bvucoep.edu.in
}

paper industry, metal processing, paint, pigments, dye, steel fabrication, batteries manufacturing, fertilizer, and biogeochemical processes, etc. is a major source of heavy metals. Additionally, acid rains, volcanic exhalations and mineral leaching in water are contributing factors to natural calamities. Breaking of soil and rocks by acid rains releases a large amount of heavy metals into water bodies and groundwater [2, 9]. Annually, effluent from fuel industry/power plant releases approximately 2.4 million tons of heavy metals to the environment [4]. While it is estimated that approximately $0.39,1.4,0.72$ million tons of heavy metals per year are released via. metal/mineral industry, agriculture, domestic waste disposal, respectively [4].

The serious effect of heavy metal contamination on man and the environment has been reported. Lead contamination in drinking water was reported in Flint, Michigan state of United State in 2014 [5]. It was due to the leaching of lead from water supply pipes. This exposure has caused serious health issues like high blood pressure, kidney and heart diseases, fertility issues, mental disturbance, pneumonia, and even killed several peoples [5]. A higher concentration of heavy metals- $\mathrm{Cu}, \mathrm{Cr}, \mathrm{Pb}, \mathrm{Hg}, \mathrm{Fe}$, and $\mathrm{Zn}$ in Kolleru lake, Andhra Pradesh, India well above world health organization (WHO) permissible limits were reported [6]. According to the central pollution control board, in 
India concentration of chromate ion 250 times more than the WHO permissible limit is reported [7]. It has caused a large effect on the aquatic life and human population in that area.

These heavy metals are of large environmental concern and have become a major threat as they are non-biodegradable and possess the properties of bioaccumulation. Their removal is highly important due to bioaccumulation properties. These metals are mobilized and carried into food chains due to contamination by leaching from waste dumps and polluted soils. Their concentration increases at every level of the food chain due to bioaccumulation/biomagnification. These metals cause large environmental, economic impact, and eminent health problems from simplest vomiting, diarrhea to major kidney failure, brain damage, cancer, etc. [1, 4]. Additionally, they disturb soil biological/ biochemical properties and activities affecting microbial/microorganism enzyme synthesis, plant nutrient recycling, chemical detoxification, pest control, etc. It results in toxicity of soil biota [8]. All these factors make contamination of water bodies by heavy metals in the effluent. It is highly dangerous for man and the environment and necessitates their removal before usage for human, animal, and agricultural purposes. Due to this a permissible limit is defined by WHO for the release of these materials through effluent [supplementary Table S1].

Secondly, these heavy metals have varied usages in different sectors. They are used as raw materials for storage batteries, pigments, glass fuels, photographic materials, explosives, and many more [2] [Table S1]. Some of them are essential for the normal development of human and animal organisms, [1] physiological functions of living tissue [9], and metabolism of proteins and carbohydrates [Table S1]. They affect deoxyribonucleic acid (DNA) replication and cell division by binding with protein molecules [1]. Details of permissible limit, sources, effect on human/animal/plant/soil, and uses of different heavy metals are given in supplementary Table $\mathbf{S 1}$.

As seen from supplementary Table $\mathbf{S 1}$, the presence of heavy metals at higher concentrations results in many adverse effects, these triggers the need for their removal from water. At the same time, these materials are highly essential in many sectors, which makes them highly valuable components. This sets the objectives for heavy metal removal and recovery. Such removal would be to protect natural water quality for the future. It would improve the chemical and ecological quality of surface water by avoiding contamination, for sustainable availability.

Stringent standards and regulations are defined by WHO promoting the removal of heavy metals to admissible level before the discharge of industrial effluent [Supplementary Table S1]. Hence efficient separation technique is required for the reduction of heavy metal concentration [1]. This separation technique should reduce the concentration of heavy metals and enable further recovery of metals [10].

Different methods are reported for removal of heavy metals, viz. chemical precipitation, ion exchange, adsorption, coagulation, flocculation, flotation, electrochemical treatment, membrane-based methods [1]. Each technique has its advantages and limitations.

\section{CONVENTIONAL PROCESSES FOR HEAVY METAL REMOVAL}

\section{Chemical Precipitation}

This process follows the steps for removal of suspended particles by filtration followed by the addition of precipitants such as sulfides/hydroxides / carbonates [11] and maintenance of $\mathrm{pH}$. A continuous stirring is provided for conversion of sparingly soluble metallic ions into the complex by reaction with chemical precipitants and formation of the insoluble metallic complex [11]. Precipitated materials can be separated by coagulation or sedimentation or filtration. It is followed by metal recovery or disposal of solid waste $[1,12]$. Treated water can be recycled or utilized further or discharged to water bodies used as a sink.

The alkaline materials such as $\mathrm{NaOH}, \mathrm{Ca}(\mathrm{OH})_{2}$ are commonly used hydroxide precipitants; which convert heavy metal ions and particles to metal hydroxides. Sodium/iron sulfide precipitants convert metal ions into metal sulfides. Similarly, sulfate-reducing bacteria (SRB) are also capable of converting sulfate to sulfide by bio metabolism. These SRB oxidizes and converts organic group into sulfide. These sulfides react with metal ions to form metal sulfides [13]. Commonly used coagulants in this process are iron salts, alum, or polymeric materials such as polyaluminium chlorohydrate or chloride or silicosulphate $[1,14,15]$.

The $\mathrm{pH}$ for efficient separation is dependent upon the type of metallic ion present. $\mathrm{pH}$ and amount of precipitant addition are dependent on the solubility of metallic ions. Different metals have different solubility 
factors. $\mathrm{pH}$ and other conditions for metallic ion might not be suitable for other $[16,17]$. e.g. Solubility of iron decreases or its removal is maximum at $\mathrm{pH} 4$ to 5 , increasing $\mathrm{pH}$ above that causes it to redissolve and concentration or solubility increases [12].

Removal efficiency and clarification abilities can be improved by combining precipitation-based methods with other treatments viz. nanofiltration, electro-fenton, ion exchange. The use of Electro- Fenton process followed by chemical precipitation for effective removal of heavy metals is reported [1, 18]. Electrochemical and Fenton treatment methods, both are part of Electro-Fenton process, provide higher efficiency. Electro-Fenton process consists of providing controlled electrical charge to anode and cathode maintained at a fixed distance in the stirred reactor containing effluent [19]. Here $\mathrm{H}_{2} \mathrm{O}_{2}$ (Fenton reagent) is continuously electrogenerated at cathode by reduction of dissolved oxygen [18]. It interacts with the heavy metal ions and initiates oxidation. This is followed by the addition of calcium oxide, which acts as a precipitant and maintains $\mathrm{pH}$. The formed precipitate can be removed by sedimentation or filtration [19]. Such in situ generations of $\mathrm{H}_{2} \mathrm{O}_{2}$ results in higher removal efficiency. It requires strong acidic conditions for the optimal removal rate of pollutants [18]. This process has higher removal efficiency with lower specific energy consumption and reaction time compared to the electrochemical process. It is more economical and environmentally friendly [18].

Chemical precipitation in combination with the ionexchange process is another hybrid separation method. It requires careful control of process conditions, viz. temperature, $\mathrm{pH}$, and time. $\mathrm{pH}$ can be adjusted by the addition of chemical precipitants. It forms insoluble metal hydroxides and is followed by contact with ion exchange resin. Here the binding and efficient separation of heavy metal ions takes place [22]. This method showed improved separation/ removal efficiency compared with chemical precipitation. Different precipitants along with removal efficiency are summarized in Table 1.

Higher removal efficiency is observed at alkaline conditions with calcium or magnesium oxide as precipitant. It is reported that separation of $\mathrm{Cu}, \mathrm{Cd}, \mathrm{Pb}$, $\mathrm{Cr}, \mathrm{Ni}, \mathrm{Fe}$ is more than $90 \%$ in the $\mathrm{pH}$ range of 8 to 11 , using calcium or magnesium oxide. This can be attributed to a reduction in metal solubility followed by precipitation at such conditions [1, 12, 21]. Similarly, maximum separation efficiency for $\mathrm{Cu}, \mathrm{Cd}$, and $\mathrm{Zn}$ at different initial concentrations using calcium,

Table 1: Chemical Precipitants/Reagents (Oxides/Hydroxide/ Sulfide /Chelating Precipitants or Fenton / ion Exchange Reagent) and their Applications in Heavy Metal lons Removal

\begin{tabular}{|c|c|c|c|c|}
\hline Metal lon & Chemical Precipitant / Reagent Dose in g/L & $\mathrm{pH}$ & \% Removal Efficiency & References \\
\hline $\mathrm{Cr}$ & $\mathrm{CaO}, \mathrm{MgO}, \mathrm{Ca}(\mathrm{OH})_{2}$ and fly ash lime precipitation & $7-11$ & 90 to $>99$ & 1,12 \\
\hline $\mathrm{Cu}$ & $\begin{array}{l}\mathrm{CaO}, \mathrm{MgO}, \mathrm{Ca}(\mathrm{OH})_{2}, \mathrm{NaOH} \\
\mathrm{H}_{2} \mathrm{~S}, \mathrm{Na}_{2} \mathrm{~S}, \mathrm{FeS}, \text { Potassium ethyl xanthate, } \\
\text { Dipropyldithiophosphate } \\
\text { STC or SDTC }\end{array}$ & $\begin{array}{c}7-12 \\
1.65-6.45 \\
5\end{array}$ & $\begin{array}{c}90 \text { to }>99 \\
94 \text { to }>99 \\
42-75\end{array}$ & $\begin{array}{c}12 \\
1 \\
20\end{array}$ \\
\hline $\mathrm{Cd}$ & $\begin{array}{l}\mathrm{MgO}, \mathrm{Fe}(\mathrm{OH})_{2}, \mathrm{Ca}(\mathrm{OH})_{2}, \mathrm{Na}_{2} \mathrm{~S} \\
\text { Dipropyldithiophosphate, SDTC }\end{array}$ & $\begin{array}{c}9.5-11 \\
3-6\end{array}$ & $\begin{array}{l}90 \text { to }>99 \\
75 \text { to }>99\end{array}$ & $\begin{array}{c}15 \\
1,20\end{array}$ \\
\hline $\mathrm{Pb}$ & $\begin{array}{l}\mathrm{CaO}, \mathrm{MgO}, \mathrm{Ca}(\mathrm{OH})_{2} \text { and fly ash } \\
\text { Dipropyldithiophosphate, } \mathrm{H}_{2} \mathrm{~S}, \mathrm{Na}_{2} \mathrm{~S} \text {, Pyrite, SDTC }\end{array}$ & $\begin{array}{c}7-11 \\
1.65-6\end{array}$ & $\begin{array}{l}90 \text { to }>99 \\
92 \text { to }>99\end{array}$ & $\begin{array}{c}1 \\
20,21\end{array}$ \\
\hline $\mathrm{Zn}$ & $\begin{array}{l}\mathrm{CaO}, \mathrm{H}_{2} \mathrm{O}_{2}, \mathrm{Ca}(\mathrm{OH})_{2}, \mathrm{H}_{2} \mathrm{~S} \text {, fly ash } \\
\mathrm{Na}_{2} \mathrm{~S}\end{array}$ & $\begin{array}{c}7-12 \\
1.65 \text { to } 3\end{array}$ & $\begin{array}{l}97 \text { to }>99 \\
94 \text { to }>99\end{array}$ & $\begin{array}{c}1 \\
19\end{array}$ \\
\hline $\mathrm{Ni}^{+2}$ & $\begin{array}{l}\mathrm{MgO}(6 \text { to } 7.5) \\
\text { Clinoptilolite ion exchanger (in } 24 \mathrm{Hr} \text { ) }\end{array}$ & $\begin{array}{l}9.5-10 \\
<6 \\
>7.5\end{array}$ & $\begin{array}{l}>90 \\
<75 \% \\
>98 \%\end{array}$ & $\begin{array}{l}12 \\
22\end{array}$ \\
\hline $\mathrm{Hg}$ & $\begin{array}{l}\text { 1,3-benzenediamidoethanethiolate, } \\
\text { Dipropyldithiophosphate }\end{array}$ & 3 to 6.4 & $>99.9 \%$ & 1 \\
\hline $\mathrm{Fe}$ & $\begin{array}{l}\mathrm{MgO} \text { ( } 3 \text { to } 7.5 \mathrm{~g} / \mathrm{L}) \\
\text { SDTC, STC, TMT }\end{array}$ & $\begin{array}{c}9.5-10 \\
4-6\end{array}$ & $\begin{array}{c}>90 \\
34 \text { to } 92\end{array}$ & $\begin{array}{l}12 \\
20\end{array}$ \\
\hline
\end{tabular}

STC: Potassium/sodium thiocarbonate; TMT: Trimercaptotriazine; SDTC: Sodiumdimethyldithiocarbamate. 
magnesium, or iron hydroxides at $\mathrm{pH} 11$ is reported $[15,21]$.

Similarly, metal oxide precipitants, $\mathrm{H}_{2} \mathrm{O}_{2}$ reagent, and Clinoptilolite ion exchange resin give better separation efficiency in the alkaline environment [19, 22]. Whereas the acidic environment is preferable for separation using sulfides, phosphates, pyrite, and iron ( $\mathrm{pH}$ 5-6), sodium at $\mathrm{pH} 1.65$, and phosphate (Dipropyldithiophosphate; pH 3-6) [1, 17, 21]. The precipitant potassium/ sodium thiocarbonate or sodium dimethyl dithiocarbamate and trimercaptotriazine also works better in the acidic environment [20].

Excellent removal efficiency and separation are reported with the precipitation-based methods using metal oxides and sulfides. Their stability and separation efficiency depends upon operating conditions of $\mathrm{pH}$, precipitant concentration, and temperature conditions. It can be further enhanced using coagulants, which form a complex with the metal ions.

Another important chemical treatment methodology is hydroxide precipitation. It is one of the widely used techniques due to its simple operation, lower cost, and ease of $\mathrm{pH}$ control. It generates a large volume of lowdensity sludge, which needs to be treated further for metal recovery or disposal [15]. The process requires maintenance of ideal $\mathrm{pH}$ for different metal ions and their efficient recovery. The separation can be further improved using sedimentation and precipitation system. Sulfide or oxide salts get precipitated, which can be easily separated from the water. The use of coagulants of biological, polymeric, or metallic origin enhances the separation efficiency. Further, the separation efficiency can also be enhanced by combining with advanced separation processes like ion-exchange, nanofiltration, or ultrafiltration combined with polymer or micellar materials. The process efficiency and separation need to be optimized separately for each of the metal components. Additionally, the presence of complexing agents in wastewater inhibits metal hydroxide precipitation [1]. Another issue with the chemical precipitation is lower separation efficiency at low effluent concentration.

Secondly, the precipitation and coagulation lead to a large amount of effluent generation. This generated effluent needs to be separated from process streams and must be treated further for material recovery or safe disposal. It leads to the generation of a large amount of solid waste and makes the processes economically and environmentally less attractive.
Similarly, in the case of a combination of ion exchange resins the activation of resins is highly essential. This activation and recovery of components are carried out by using chemicals, which generates secondary pollutants.

Electrocoagulation is another modification to avoid sludge generation and economic issues due to the use of a large amount of chemicals. It involves in situ generations of chemicals using electrical current passed through the solutions. The separation efficiency depends upon current efficiency, charge, charge density, $\mathrm{pH}$, and other solution properties. It is reported that Electrocoagulation (EC) is preferable over chemical precipitation as it does not require the addition of chemicals. Additionally, the use of EC results in low sludge production and improved efficiency in terms of removal of components and species compared to chemical precipitation. Selection of precipitant, design of precipitation system, optimization of process conditions and operating parameters are highly essential. The generation of chemicals and their disposal with the proper design of disposal sites is highly important. Lack of necessary binding sites makes handling precipitants difficult. The new and more effective precipitants, chelating precipitant meets the need of discharge [2]. It possesses active binding sites with higher selectivity for a given metal ion. This makes them highly selective for binding or combining with the material. A formed complex is easy for separation and recovery. Though they have many advantages, there are certain limitations. There is a need for specific synthesis and economic issues are aligned with them.

\section{Ion Exchange}

Ion exchange depends upon sorption by the interaction of polar ions. It is one of the potentially important methods for the separation of heavy metal ions. It works on the exchange of similarly charged ions between an electrolyte (substrate) and surrounding medium [4]. Commercially available ion exchangers are either cation, anion, or amphoteric in nature. Polymeric resins modified to provide desired ion exchange characteristics for practical applications. The process is carried out by preparing an ion exchange bed, where the exchange takes place in contact with metal ions. These ions bind to resins based on their chemical structure.

Commonly used cation exchange resins are strong acid resins with sulfonic acid groups $\left(-\mathrm{SO}_{3} \mathrm{H}\right)$ and weak 
acid resins with carboxylic acid groups $(-\mathrm{COOH})$ [15]. They work at a wide range of $\mathrm{pH}$, whereas weak acid resins show good sorption capacity at $\mathrm{pH}$ greater than 7 [4]. These resins possess good selectivity for heavy metals. Their forms bond with the heavy metal ions and bind on the active sites. Treated water can be sent for further applications or processes. The resin bed is regenerated by treatment with acid or caustic solution. The separation capacities of different resins towards heavy metals are summarized in Table 2.

The separation efficiency of heavy metal is dependent upon properties of ion exchange resin, solution concentration, and operating conditions like $\mathrm{pH}$, temperature, contact time, ionic charge, etc. An increase in $\mathrm{Pb}$ and $\mathrm{Cd}$ removal in an acidic environment is reported. A better ion removal efficiency by ion exchange is reported at a solution concentration of $10-100 \mathrm{mg} / \mathrm{L}$ and $\mathrm{pH}$ of $2-6$ [15]. It is reported that metals with more free ions will be absorbed preferably and separated. Further, the adsorption and separation are also dependent upon metal ion reactivity and other properties, e.g. adsorption varies as $\mathrm{Ce}^{4+}>\mathrm{Fe}^{3+}>\mathrm{Pb}^{2+}$ [1]. The adsorption capacity reduces with the saturation at equilibrium [24]. It can be seen from similar separation efficiency $\mathrm{Cr}(\mathrm{III})$ at a concentration between $10-100 \mathrm{mg} / \mathrm{L}$ and $\mathrm{Ni}$, Cu concentration up to $100 \mathrm{mg} / \mathrm{L}$ having separation efficiency of 100 and $>90 \%$, respectively [15].

Ion exchange is a relatively cheap and faster process. It can be utilized in portable columns. The used and saturated resin beds need regeneration by removing sorbed metal ions. This is carried out by backwashing, flushing, and rinsing. It required the use of chemicals for the regeneration of ion exchange resin. This results in secondary pollution and arises the need for treatment of a large quantity of effluent generated from regeneration [15]. This adds up to the processing expenses while creating disposal or recovery problem for removed metal ions.

\section{Adsorption}

Adsorption is one of the physicochemical treatment processes [25]. It is based on transferring components or materials to be adsorbed (adsorbate) from the liquid phase onto solid surface (adsorbent) by mass transfer [15]. Adsorbate is bound to the surface of adsorbent by physical or chemical interactions. Adsorbents are regenerated by desorption using appropriate eluent [32]. This results in separation of components and cleaning of the effluent.

Chemically active adsorbents can be generated from waste or by-products. These are called low-cost adsorbents. They are natural material or waste generated in agriculture or industry processes e.g. sawdust, clinoptilolite, kaolinite, etc. [26, 27]. Apart from this animal and plant-based bio-adsorbents are also used for heavy metal separation. Some of the bioadsorbents are (1) non-living biomass, (2) algal biomass, and (3) microbial biomass [1]. Agricultural/forest/industrial waste and algae can also

Table 2: Ion Exchange Resins and their Application in Heavy Metal lons Removal

\begin{tabular}{|c|c|c|c|c|}
\hline Metal Ion & Resin & $\mathrm{pH}$ & Removal Efficiency (\%) & References \\
\hline $\mathrm{Pb}(\mathrm{II})$ & $\begin{array}{l}\text { Clinoptilolite zeolite } \\
\text { Clinoptilolite zeolite }\end{array}$ & $\begin{array}{l}1-8 \\
>8\end{array}$ & $\begin{array}{l}100 \\
<80\end{array}$ & 23 \\
\hline $\mathrm{Cd}(\mathrm{II})$ & $\begin{array}{l}\text { Clinoptilolite zeolite, Clinoptilolite, NaP1 zeolite } \\
\text { Clinoptilolite zeolite }\end{array}$ & $\begin{array}{r}4-10 \\
>10\end{array}$ & $\begin{array}{l}>90 \\
<70\end{array}$ & $\begin{array}{l}23 \\
15\end{array}$ \\
\hline $\mathrm{Cr}(\mathrm{III})$ & $\begin{array}{l}\text { Clinoptilolite,NaP1 zeolite,Dowex 2-X4,IRN77,SKN1 } \\
\text { Amberjet1200H, Amberlite IRN97H }\end{array}$ & $\begin{array}{l}\text { NA } \\
2-6\end{array}$ & $\begin{array}{c}90-100 \\
100\end{array}$ & 15 \\
\hline $\mathrm{Cr}(\mathrm{VI})$ & $\begin{array}{l}\text { Clinoptilolite zeolite, } \\
\text { Solvent Impregnated resin with aliquat } \\
\text { Dowex 2-X4, Ambersep } 13\end{array}$ & $\begin{array}{c}4-12 \\
5 \\
\text { NA }\end{array}$ & $\begin{array}{c}<15 \\
99.5 \\
100\end{array}$ & $\begin{array}{l}23 \\
15\end{array}$ \\
\hline $\mathrm{Ni}(\mathrm{II})$ & Clinoptilolite, Synthetic (NaP1) zeolite & NA & 90 to 100 & $\begin{array}{c}1 \\
15\end{array}$ \\
\hline $\mathrm{Zn}(\mathrm{II})$ & Clinoptilolite, Amberlite IR-120, Synthetic (NaP1) zeolite & 5 & 90 to 100 & $\begin{array}{c}1 \\
15\end{array}$ \\
\hline $\mathrm{Cu}(\mathrm{II})$ & Clinoptilolite, Synthetic (NaP1) zeolite & NA & 90 to 100 & 15 \\
\hline
\end{tabular}

NA-Not available. 
be used as low-cost bio-adsorbents [28]. Their adsorption capacity and efficiency depend upon the processing, porosity, and chemical composition. The adsorption capacity and equilibrium conditions can be modified by chemical treatment $[29,30]$. e.g. Acid treated fruit/ vegetable waste/peels have better adsorption than alkali and water treated [30]. These adsorbents are mainly classified as low-cost inorganic adsorbents, activated carbon (AC) adsorbents, carbon nanotubes (CNTs) -single-walled (SWCNT) and multiwalled (MWCNT) and bio-adsorbents.

AC adsorbents are highly porous, amorphous solid. They possess large surface area and large micropore and mesopore volumes [15, 26]. These adsorbents can be prepared from various sources. Their composition and separation efficiencies are changed based upon composition of source material, it is quality and treatment methodology [1]. e.g. AC obtained from bituminous coal or coconut shell has less adsorption capacity compared to poultry litter-based AC. Further $A C$ can be modified by using suitable additives such as alginate, tannic acid, magnesium surfactants. It increases the adsorption efficiency for heavy metals separation [1]. Hazelnut, rice husk modified chemically or converted into activated carbon by heating shows better adsorption performance than raw [25]. Ahmadijokani F. et al. 2021 reported that for adsorbent UiO-66-EDA, adsorption capacity increases with an increase in agitation time, $\mathrm{pH}$, and adsorbent dosage. Adsorption capacity of different adsorbent is shown in Table 3.

CNTs are another carbon-based adsorbent classified as single/multi-walled CNTs (SWCNTs/MWCNTs). Conventional neutral CNTs possess low adsorption capacity [32]. The sorption capacity can be improved by treating CNTs using acid treatment $\left(\mathrm{HNO}_{3}, \mathrm{H}_{2} \mathrm{SO}_{4}, \mathrm{HCl}\right)$, oxidation $(\mathrm{KMnO} 4$, $\mathrm{H}_{2} \mathrm{O}_{2}, \mathrm{NaOCl}$ ), grafting or treatment with metal oxides $\left(\mathrm{MnO}_{2}, \mathrm{Al}_{2} \mathrm{O}_{3}, \mathrm{FeO}\right)$ [32]. Grafting of functional groups on CNTs can be done by plasma technique, microwave irradiation etc. The reaction conditions, methods and

Table 3: Adsorbents and their Application in Heavy Metal lons Removal

\begin{tabular}{|c|c|c|c|c|}
\hline Metal Ion & pH & Adsorbent & Adsorption Capacity/ Removal \% & References \\
\hline $\mathrm{As}(\mathrm{V})$ & 6 & MWCNT-zirconia & $5000 \mu \mathrm{g} / \mathrm{g}$ & 32 \\
\hline As(III) & $\begin{array}{l}6 \\
8\end{array}$ & $\begin{array}{l}\text { MWCNT zirconia } \\
\text { Fe-MWCNT }\end{array}$ & $\begin{array}{c}2000 \mu \mathrm{g} / \mathrm{g} \\
4 \mathrm{mg} / \mathrm{g}\end{array}$ & 32 \\
\hline $\mathrm{Cd}(\mathrm{II})$ & $\begin{array}{c}7 \\
7 \\
6.5-6.8 \\
\text { NA } \\
\text { NA } \\
6\end{array}$ & $\begin{array}{l}\text { Oxidised CNT } \\
\text { Acidified CNT } \\
\text { Prestine MWCNT } \\
\text { Clinoptilolite } \\
\text { Clinoptilolite } \\
\text { UiO-66-EDA }\end{array}$ & $\begin{array}{c}92.59 \mathrm{mg} / \mathrm{g} \\
4.35 \mathrm{mg} / \mathrm{g} \\
0.05 \mathrm{mmol} / \mathrm{g} \\
4.22 \mathrm{mg} / \mathrm{g} \\
23.6 \mathrm{mg} / \mathrm{L} \\
205.96 \mathrm{mg} / \mathrm{g}\end{array}$ & $\begin{array}{l}32 \\
27 \\
31\end{array}$ \\
\hline $\mathrm{Ni}(I I)$ & $\begin{array}{c}5 \\
3.5 \\
8 \\
\text { NA }\end{array}$ & $\begin{array}{l}\text { AC(prepared at } 900 \mathrm{~K}) \\
\text { MWCNT/iron oxide } \\
\text { MWCNT/iron oxide } \\
\text { Clinoptilolite }\end{array}$ & $\begin{array}{c}100 \% \\
\approx 10 \% \\
\approx 80 \% \\
13.03 \mathrm{mg} / \mathrm{g}\end{array}$ & $\begin{array}{l}21 \\
27\end{array}$ \\
\hline $\mathrm{Cu}(\mathrm{II})$ & $\begin{array}{c}5 \\
5 \\
\text { NA } \\
6\end{array}$ & $\begin{array}{l}\text { CNT } \\
\text { Calcium alginate CNT } \\
\text { CNT, Brine sediments, Sawdust, } \\
\text { Clinoptilolite } \\
\text { UiO-66-EDA }\end{array}$ & $\begin{array}{c}74.8 \% \\
84.88 \mathrm{mg} / \mathrm{g} \\
2.31-25.76 \mathrm{mg} / \mathrm{g} \\
188.08 \mathrm{mg} / \mathrm{g}\end{array}$ & $\begin{array}{l}21 \\
32 \\
27 \\
31\end{array}$ \\
\hline $\begin{array}{l}\mathrm{Cr}(\mathrm{III}) \\
\mathrm{Cr}(\mathrm{VI})\end{array}$ & $\begin{array}{c}7 \\
8 \\
2.85 \\
2.85 \\
3 \\
7.8\end{array}$ & $\begin{array}{l}\text { Raw MWCNT } \\
\text { Nitrogened doped magnetic CNT } \\
\text { Oxidised MWCNT } \\
\text { Oxidised MWCNT } \\
\text { Raw MWCNT } \\
\text { Acidified CNT }\end{array}$ & $\begin{array}{c}0.3853 \mathrm{mg} / \mathrm{g} \\
83.75 \mathrm{mmol} / \mathrm{g} \\
100 \% \\
50 \% \\
3.115 \mathrm{mg} / \mathrm{g} \\
249 \mu \mathrm{mol} / \mathrm{g}\end{array}$ & $\begin{array}{l}32 \\
21 \\
32\end{array}$ \\
\hline $\mathrm{Pb}$ & 6 & UiO-66-EDA & $239.85 \mathrm{mg} / \mathrm{g}$ & 31 \\
\hline
\end{tabular}

NA-Not available. 
treatment parameters need to be carefully optimized to obtain desired sorption capabilities. The adsorption capacity of both functional-nonfunctional SWCNTs and MWCNTs is better as compare to AC [21, 32]. These CNTs have good separation efficiency but possess possible health risks. Hence, they need to be modified by suitable environment-friendly adsorbent (like calcium alginate) before application [1, 32]. Though these CNTs shows good adsorption capacity, their recovery is difficult, it remains in effluent stream and imparts toxicity of CNTs in water [33].

The sorption efficiency is dependent upon solution parameters as $\mathrm{pH}$, metal ion concentration and solution composition. Ionic strength adversely affects the activity coefficient of ions decreases, in turn, the sorption efficiency. It is further dependent upon the concentration and number of active sites on adsorbent. Table 4 shows adsorption capacity of non-living plant/ animal bio-adsorbents.

The separation is dependent upon composition of solution, lower sorption and separation efficiency in multicomponent systems compared to singlecomponent systems is reported. This can be attributed to the comparative and preferable sorption properties. Further, the separation is dependent upon $\mathrm{pH}$, temperature, structure, surface area and functional group present $[25,35-38]$. Also, it depends on temperature, $\mathrm{pH}$, and ionic strength of water to be treated [38]. The biochar production and activation through physical and chemical treatment increases surface area and pore volume of adsorbent and hence will improve adsorption [39]. The separation selectivity for adsorbent is lower. Its efficiency depends on composition and interactive properties. The adsorption bed needs to be regenerated upon completion of sorption and saturation of bed. The regeneration is done by rinsing and backwash. It uses chemicals and generates large amount of secondary waste. This waste needs to be treated for metal recovery and generates large amount of secondary waste. This results in large disposal and regeneration issues [32].

\section{Coagulation, Flocculation and Flotation}

\subsection{Coagulation}

It works on formation of hydrophobic collides from suspended particles [1]. They can be separated by settling or filtration. Separated colloids are disposed or used in metal recovery. Generated sludge is easy to process due to quick settling and dewatering property.
Commonly used coagulants for heavy metal separation are aluminum, ferrous sulfate and ferric chloride, polyaluminum chloride (PACl) and magnesium chloride $\left(\mathrm{MgCl}_{2}\right)$ etc. [40]. The formation of colloidal complex and their separation is dependent upon $\mathrm{pH}$ and operating parameters. Separation of negative materials is facilitated at low $\mathrm{pH}$; while high $\mathrm{pH}$ is beneficial for positively charged materials $[1,15]$.

\subsection{Flocculation}

It works on formation of flocs or binding of particles into clumps [26]. Clumps or flocs are low-density porous suspended structures, which rises to surface along with gases bubbled through solution. Suspended particles (clumps) are removed by filtration or floatation. Different flocculants of organic, inorganic or polymeric nature are used for separation of heavy metals e.g. Polyferricsulfate (PFS), polyacrylamide and polyampholyte chitosan [15].

In the coagulation- flocculation process, initially, coagulants are added to water. It destabilizes colloids, followed by separation of unsettled ions in the form of bulky flocs using flocculants [15]. It is used for efficient removal of heavy metal ions and turbidity. The applicability of process is limited due to production, disposal cost of large quantity of sludge and regeneration/ recovery issues of heavy metals [32, 35].

\subsection{Flotation}

This method is based on modification of unique surface and wetting characteristics possessed by particles [41]. These surface properties of heavy metals can be modified using surfactant to form an agglomerate. They can be separated by bubbling air in liquid to form froth of hydrophobic particles with an air bubble. The formed froth is removed and used or sent for further purification [41]. Different methods are used for flotation-based separation like dissolved air flotation (DAF), dispersed-air flotation, vacuum air flotation, electro-flotation, biological flotation, and precipitation flotation [15, 41]. The flotation process has good efficiency for metal removal and sludge production. This results in easy separation. It has issues with high capital, maintenance, and operation cost $[32,35]$.

The method requires addition of precipitants, surfactants, and collectors for easy formation of flocculants. Ethanol and methyl isobutyl carbinol as surfactant, and sodium dodecyl sulphate and hexadecyltrimethylammonium bromide are used as 
Table 4: Agricultural Waste/ Non-living Plant Material/ Non-living Animal Material/ Algae / Fungi / Bacteria / Yeast Adsorbent and their application in Heavy Metal lons removal

\begin{tabular}{|c|c|c|c|c|}
\hline $\begin{array}{c}\text { Metal } \\
\text { Ion }\end{array}$ & Adsorbent / Modifying Agent & $\mathrm{pH}$ & $\begin{array}{l}\text { Adsorption Capacity } \\
\text { (mg/g), Removal\% }\end{array}$ & References \\
\hline $\mathrm{Cd}(\mathrm{II})$ & $\begin{array}{l}\text { Cedrus deodar wood sawdust / } \mathrm{NaOH} \\
\text { Rice Husk, Juniper fibre/ Water/Base/ Epichlorohydrin } \\
\text { Pinussylvestris/ walnut sawdust, Cassava waste, Spent grain Corncorb / } \\
\mathrm{CHOH/Acid} \\
\text { Wheat bran / } \mathrm{H}_{2} \mathrm{SO}_{4} \\
\text { Azollafiliculoides(aquatic fern)/ Hydrogen peroxide-MgCl } \\
\text { Sugarcane bagasse/ } \mathrm{NaHCO}_{3} / \text { Triethylenetetramine } \\
\text { PVA immobilised biomass, Fungal biomass } \\
\text { Enterobacter cloacae Bacillus, Aspergillus cristatus } \\
\text { Pseudomonas sp./ Actinomycete sp }\end{array}$ & $\begin{array}{l}\text { NA } \\
\text { NA } \\
\text { NA } \\
\text { NA } \\
\text { NA } \\
5.5 \\
5-6 \\
4.5\end{array}$ & $\begin{array}{l}73.62 \\
8.5 \text { to } 29.5 \\
<26 \\
101 \\
86 \\
189-313 \\
7-15 \% \\
23-58.9 \% \\
90-95 \%\end{array}$ & $\begin{array}{c}30 \\
34,35\end{array}$ \\
\hline $\mathrm{Cr}(\mathrm{VI})$ & $\begin{array}{l}\text { Sawdust(S.Robusta)/oak tree, groundnut husk/ Formaldehyde/ Acid } \\
\text { TerminaliaArjunaNuts/Coirpith / } \mathrm{ZnCl}_{2} \\
\text { Coconut shell charcoal/ Rice husk/modified rice hull } \\
\text { Enterobacter cloacae Bacillus, Sargassum sp. } \\
\text { Micrococcus sp. }\end{array}$ & $\begin{array}{l}\text { NA } \\
\text { NA } \\
\text { NA } \\
4 \\
5\end{array}$ & $\begin{array}{c}<11.4 \\
28.43 \\
0.79-23.4 \\
55.8-68.9 \% \\
92 \%\end{array}$ & $\begin{array}{c}30 \\
25,35\end{array}$ \\
\hline $\mathrm{Cr}(I I I)$ & $\begin{array}{l}\text { Peanut husk/ Sulfuric acid } \\
\text { Bagasse fly ash/ Hydrogen peroxide }\end{array}$ & & $\begin{array}{l}7.67 \\
4.35\end{array}$ & 30 \\
\hline $\mathrm{Cu}(\mathrm{II})$ & $\begin{array}{l}\text { Poplar/oak tree sawdust, rice/peanut husk, Banana pith, Cork powder, } \\
\text { Sugarcane bagasse, Groundnut/peanut shells, Indian barks-sal/ mango/ } \\
\text { jackfruit, Carrot residues/ Acid, Base, Chlorides } \\
\text { Saw dust, jute fiber/ Reactive Orange } 13 \\
\text { Sugarcane bagasse/ } \mathrm{NaHCO}_{3} / \text { Ethylene diamine/ } \\
\text { Triethylenetetramine } \\
\text { Pecan shells activated carbon } \\
\text { Enterobacter Cloacae Bacillus, Bacillus sp. } \\
\text { Living mycelium of phanerochaetechrysosporium macroalga } \\
\text { Chaetomorphalinum (20g/L) }\end{array}$ & $\begin{array}{l}\text { NA } \\
\text { NA } \\
\text { NA } \\
5\end{array}$ & $\begin{array}{c}<40 \\
<9 \\
114-140 \\
31.7 \\
69.34-78.9 \% \\
90.6 \%\end{array}$ & $\begin{array}{l}30 \\
25 \\
35\end{array}$ \\
\hline $\mathrm{Pb}(\mathrm{II})$ & $\begin{array}{l}\text { Rice husk / Tartaric acid } \\
\text { Pinussylvestris/ Walnut sawdust, Peanut husk/ } \mathrm{HCOH} \text { and } \mathrm{H}_{2} \mathrm{SO}_{4} \\
\text { Banana stem/ } \mathrm{NaOH} \\
\text { Azollafiliculoides, Sugarcane bagasse/ } \mathrm{NaHCO}_{3} / \text { amine/ Hydrogen } \\
\text { peroxide } \\
\text { Staphylococcus saprophyticus } \\
\text { Enterobacter cloacae Bacillus, Rhizopus nigricans Calotropis procera(Ait) }\end{array}$ & $\begin{array}{l}\text { NA } \\
\text { NA } \\
\text { NA } \\
\text { NA } \\
4.5 \\
5-5.5 \\
4\end{array}$ & $\begin{array}{l}120.48 \\
<29 \\
91.74 \\
164-313 \\
100 \% \\
67.9-80.8 \% \\
22.8 \%\end{array}$ & $\begin{array}{l}30 \\
35\end{array}$ \\
\hline $\mathrm{Zn}(\mathrm{II})$ & $\begin{array}{l}\text { Maize cope and husk } \\
\text { Sawdust (Poplar tree), Groundnut shells / } \mathrm{NaOH}, \mathrm{HCl} \\
\text { Maize husk } \\
\text { Sawdust, Brine sediments, Jute fibres/ Reactive Orange } 13 \\
\text { Cassava tuber bark waste/ Thioglycollic acid } \\
\text { SRB, Pseudomonas Aeruginosa, Green algae } \\
\text { Thiobacillus } \\
\text { Macroalga haetomorphalinum } \\
\text { Brine sediments, Sawdust }\end{array}$ & $\begin{array}{l}\text { NA } \\
\text { NA } \\
\text { NA } \\
\text { NA } \\
\text { NA } \\
5 \\
5 \\
5\end{array}$ & $\begin{array}{c}495.9 \\
<30 \\
13.4 \\
2.5-17 \\
83.3 \\
5.6-7.62 \% \\
95.24 \% \\
0.25-1.05 \mathrm{mmol} / \mathrm{g}\end{array}$ & $\begin{array}{c}25 \\
1 \\
35 \\
36\end{array}$ \\
\hline $\mathrm{Ni}(\mathrm{II})$ & $\begin{array}{l}\text { Orange peel } \\
\text { Walnut sawdust/ } \mathrm{HCOH} \text { and } \mathrm{H}_{2} \mathrm{SO}_{4} \\
\text { Sawdust, Jute fibres, Groundnut shells/ Reactive Orange } 13 \\
\text { Coirpith / } \mathrm{H}_{2} \mathrm{SO}_{4} \text { and }\left(\mathrm{NH}_{4}\right)_{2}\left(\mathrm{SO}_{4}\right)_{2} \\
\text { Micrococcus sp. } \\
\text { Actinomycete } \mathrm{sp}(5 \mathrm{~g} / \mathrm{L})\end{array}$ & $\begin{array}{l}\text { NA } \\
\text { NA } \\
\text { NA } \\
\text { NA } \\
5 \\
6\end{array}$ & $\begin{array}{c}158 \\
6.43 \\
<10 \\
62.5 \\
90 \% \\
36.55 \%\end{array}$ & $\begin{array}{l}25 \\
35\end{array}$ \\
\hline
\end{tabular}




\begin{tabular}{|c|l|c|c|}
\hline $\mathrm{Fe}$ & Brown algae(Sargassum sp.), Candida spp, Saccharomyces cervisiae & $3-7$ & 35 \\
\hline $\mathrm{Hg}(\mathrm{II})$ & $\begin{array}{l}\text { Aspergillus flavus I-V, Aspergillus fumigatus I-II, } \\
\text { Saccharomyces cervisiae }\end{array}$ & $5.5-7$ & $76-95.3$ \\
\hline $\begin{array}{c}\text { As(III)A } \\
\text { (V) }\end{array}$ & Spirogyra hyaline, PchrysogenumWaste tea fungi & 35 & 3.719 \\
\hline
\end{tabular}

PVA-Poly vinyl alcohol, NA-Not available, SRB-Sulphate-reducing bacteria.

precipitant [1] Polyamines, diallyl dimethyl ammonium chlorides (DADMAC), polyacrylamides (PAMs), polyvinyl alcohol (PVA), modified PVA, polyethylene glycol (PEG), and chitosan are used as collector [15, 41]. The separation efficiency of metal ions using coagulants, flocculants are shown in Table $\mathbf{5}$.

The coagulation-flocculation process is effective in $\mathrm{pH}$ (11 to 11.5), surfactant and flocculant loading, concentration, and operation conditions for each of the components are different for each of the metal ion and needs to be optimized for each of the metal ions separately. This requires further addition of chemicals and improves the process cost due to chemical consumption [15]. It is observed that for removal capacity for metal ion concentration is maximum for 50 to $250 \mathrm{ppm}$ of $\mathrm{Cd}, \mathrm{Pb}, \mathrm{Ni}, \mathrm{Fe}, \mathrm{Mn}$ by using chitosan as compare with PVA, PEG [41]. Zeolite and chabazite collectors have more than $95 \%$ removal efficiency for metal ions [15].

Table 5: Coagulants-Flocculants and their Application in Heavy Metal lons Removal

\begin{tabular}{|c|c|c|c|c|c|}
\hline Metal Ion & Coagulant/Precipitant & Collector & $\mathrm{pH}$ & $\begin{array}{l}\text { \%Removal } \\
\text { Efficiency }\end{array}$ & References \\
\hline $\mathrm{Zn}(\mathrm{II})$ & $\begin{array}{c}\mathrm{Na}_{2} \mathrm{~S} \\
\mathrm{Fe}(\mathrm{OH})_{3} \\
\mathrm{NA}\end{array}$ & $\begin{array}{c}\text { NA } \\
\text { Chabazite } \\
\text { PVA9000/10000/13000/35000, } \\
\text { Chitosan }\end{array}$ & $\begin{array}{l}11 \\
5.5 \\
\text { NA }\end{array}$ & $\begin{array}{l}92 \text { to }>99 \\
98.6 \\
24 \text { to } 26.5\end{array}$ & $\begin{array}{l}15 \\
40 \\
41\end{array}$ \\
\hline $\mathrm{Cu}(\mathrm{II})$ & $\begin{array}{l}\text { Poly-ferric sulphate-25, Poly- } \\
\text { acrylamide-5 } \\
\mathrm{Fe}(\mathrm{OH})_{3}-30.9 \\
\text { SDS }\end{array}$ & $\begin{array}{l}\text { NA } \\
\text { Chabazite-0.5 } \\
\text { Trien / Zeolite }\end{array}$ & $\begin{array}{c}10-11.5 \\
5.5 \\
5-6.7\end{array}$ & $\begin{array}{c}95 \text { to } 99.6 \\
98.26 \\
85-97\end{array}$ & $\begin{array}{l}15 \\
40 \\
15\end{array}$ \\
\hline $\mathrm{Pb}(\mathrm{II})$ & $\begin{array}{c}\text { PACl-150,600,800,1200 } \\
\mathrm{MgCl}_{2}-600 / 1200 / 2000 / 4000 / 6000 \\
\text { Alum- } 200 / 600 / 1200 / 2000 / 4000\end{array}$ & NA & $\begin{array}{l}7.6-9.1 \\
6.9-12.5\end{array}$ & $\begin{aligned} &>99 \\
& 89 \text { to }>99.5\end{aligned}$ & 40 \\
\hline $\mathrm{Ni}(\mathrm{II})$ & $\begin{array}{l}\mathrm{Fe}(\mathrm{OH})_{3}-20 \\
\mathrm{SDS} \\
\mathrm{NA}\end{array}$ & $\begin{array}{c}\text { Chabazite- } 0.5 \\
\text { Trien-0.015 } \\
\text { PVA9000/13000, PEG10000/ } \\
35000 \\
\text { Chitosan }\end{array}$ & $\begin{array}{c}5.5 \\
7 \\
\text { NA }\end{array}$ & $\begin{array}{c}98.6 \\
70 \\
23.5-26\end{array}$ & $\begin{array}{l}15 \\
41\end{array}$ \\
\hline $\mathrm{Cr}(\mathrm{VI})$ & $\begin{array}{l}\text { Magnafloc-3 } \\
\text { Ferric hydroxide-600 }\end{array}$ & $\begin{array}{c}\text { Hydrotalcite } \\
\text { Surfactin-105-0.04 }\end{array}$ & $\begin{array}{c}\text { NA } \\
4\end{array}$ & $\begin{array}{l}95 \\
98\end{array}$ & 15 \\
\hline $\mathrm{Mn}(\mathrm{II})$ & $\begin{array}{l}\mathrm{Na}_{2} \mathrm{~S}-100 \\
\mathrm{NA}\end{array}$ & $\begin{array}{c}\text { NA } \\
\text { PVA9000/13000, PEG10000/ } \\
35000 \\
\text { Chitosan }\end{array}$ & $\begin{array}{r}11 \\
\text { NA }\end{array}$ & $\begin{array}{c}99.95 \\
22.5-32\end{array}$ & $\begin{array}{l}15 \\
41\end{array}$ \\
\hline $\mathrm{Cd}(\mathrm{II})$ & $\begin{array}{l}\mathrm{Na}_{2} \mathrm{~S}-100 \\
\mathrm{NA}\end{array}$ & $\begin{array}{c}\text { NA } \\
\text { PVA9000/ 13000, } \\
\text { PVA10000/ 35000, } \\
\text { Chitosan }\end{array}$ & $\begin{array}{r}11 \\
\mathrm{NA}\end{array}$ & $\begin{array}{l}99.73 \\
23-29\end{array}$ & 15 \\
\hline $\begin{array}{c}\mathrm{Pb}\left(\mathrm{NO}_{3}\right)_{2} \\
\mathrm{PbCl}_{2}\end{array}$ & $\begin{array}{l}\text { NA } \\
\text { NA }\end{array}$ & $\begin{array}{c}\text { PVA9000/ 10000/ 13000/ } 35000 \\
\text { Chitosan, PVA9000 }\end{array}$ & $\begin{array}{l}\text { NA } \\
\text { NA }\end{array}$ & $\begin{array}{c}19.5-26.5 \\
20-28.5\end{array}$ & 41 \\
\hline
\end{tabular}

PEG-Polyethylene glycol, PVA-Polyvinyl alcohol, SDS-Sodium Dodecyl Sulfate, NA-Not available. 


\section{Electrochemical Treatment}

In this case separation of ions through chemically modified solutions takes place with the help of electrical current. The anode and cathode are placed in water bath lead to generation of hydrogen and oxygen due to half-cell reaction in presence of an electrical current. They carry out the oxidation and reduction reactions in the solution and help to separate the sludge from water to surface. The redox reaction, hydrogen and oxygen generation can be triggered and enhanced by use of catalytic chemicals. Heavy metals are separated from flocs collected on the solution surface or would be accumulated on cathode in pure form [42].

Generally, iron and aluminum electrodes are commonly used in electro-coagulation process. The iron or aluminum electrodes get dissolved in solution and act as coagulants for separation. Generated gases work as flocculent and lead to separation of material by coagulation and flotation. Table 6 shows separation by electro-chemical (electro-coagulation/electro-floatation /electrodeposition) method.

The separation efficiency of metal ions is dependent upon many process parameters along with the electrical current density, solution properties. The material of construction of electrode, $\mathrm{pH}$ of solution and distance between electrodes, solution conductivity, type of power supply, an arrangement of electrodes, current density, distance between electrodes, electrolysis time will affect heavy metal removal efficiency by electrochemical method [1, 42, 43]. Solutions with higher conductivity increase current density which enhances removal efficiency with reduction in energy consumption. Hence, conductivity of solution is adjusted by addition of electrolyte salt.

Further the amount of coagulant amount, rate of bubble production and size of flocs produced to

Table 6: Separation of Heavy Metals by Electro-Chemical Method

\begin{tabular}{|c|c|c|c|c|c|}
\hline Metal lon & Electrode & $\mathrm{pH}$ & Current Density $\left(\mathrm{mA} / \mathrm{cm}^{2}\right)$ & Separation Efficiency (\%) & References \\
\hline $\mathrm{Cr}$ & $\begin{array}{c}\text { Fe-Fe, } \\
\text { Al-Fe } \\
\text { Fe-S 304, Fe-Al, Al-Al }\end{array}$ & $\begin{array}{c}7-9.56 \\
1.84 \\
3-6.9\end{array}$ & $\begin{array}{c}\mathrm{NA} \\
7.4 \mathrm{~mA} / \mathrm{cm}^{2} \\
\mathrm{NA}\end{array}$ & $\begin{array}{c}70-100 \\
100 \\
83-100\end{array}$ & $\begin{array}{c}43 \\
1 \\
21\end{array}$ \\
\hline $\mathrm{Cu}(\mathrm{II})$ & $\begin{array}{c}\text { Al-Fe, Al-Al-Al, Fe } \\
\text { Al-Fe }\end{array}$ & $\begin{array}{c}3-5.7 \\
6\end{array}$ & $\begin{array}{c}\mathrm{NA} \\
0.3 \mathrm{~mA} / \mathrm{cm}^{2}\end{array}$ & $\begin{array}{c}100 \\
98-99\end{array}$ & $\begin{array}{c}43 \\
21 \\
1\end{array}$ \\
\hline $\mathrm{Ni}(I I)$ & $\begin{array}{c}\mathrm{Al}-\mathrm{Fe}, \mathrm{Fe}, \mathrm{SS}_{304}-\mathrm{S}_{304} \\
\mathrm{Al}-\mathrm{Fe}\end{array}$ & $\begin{array}{c}3-6.9 \\
6\end{array}$ & $\begin{array}{c}\mathrm{NA} \\
9 \mathrm{~mA} / \mathrm{cm}^{2}\end{array}$ & $\begin{array}{c}96-100 \\
100\end{array}$ & $\begin{array}{c}21 \\
1,43\end{array}$ \\
\hline $\mathrm{Pb}(\mathrm{II})$ & $\mathrm{Al}-\mathrm{SS}, \mathrm{Fe}-\mathrm{Fe}$ & $6-8$ & $30-40$ & 95 & 21 \\
\hline $\mathrm{Zn}(\mathrm{II})$ & $\begin{array}{c}\text { Al-SS } \\
\text { Al-Al-Al, Fe } \\
\text { Fe-Fe } \\
\text { SS }_{304}-S_{304} \\
\text { Al-Fe }\end{array}$ & $\begin{array}{c}\text { NA } \\
4-5.7 \\
9.56 \\
\text { NA } \\
6\end{array}$ & $\begin{array}{l}\text { NA } \\
\text { NA } \\
\text { NA } \\
\text { NA } \\
9\end{array}$ & $\begin{array}{c}68 \\
83-96 \\
96 \\
100 \\
100\end{array}$ & $\begin{array}{c}43 \\
21 \\
1\end{array}$ \\
\hline $\mathrm{Cd}$ & $\begin{array}{l}\text { Al-SS } \\
\text { Zn-Zn } \\
Z n\end{array}$ & $\begin{array}{c}\text { NA } \\
7 \\
2.61-3.5\end{array}$ & $\begin{array}{c}\text { NA } \\
0.1 / 0.3 / 0.5 \mathrm{Adm}^{-2} \\
\text { NA }\end{array}$ & $\begin{array}{c}66 \\
94-98.5 \\
72-92.2\end{array}$ & $\begin{array}{l}43 \\
21 \\
44\end{array}$ \\
\hline $\mathrm{Mn}$ & $\begin{array}{c}\mathrm{Fe} \\
\mathrm{Al}-\mathrm{Fe}\end{array}$ & $\begin{array}{c}5.5-5.7 \\
7\end{array}$ & $\begin{array}{l}\text { NA } \\
6.25\end{array}$ & $\begin{array}{l}72.6 \\
78.3\end{array}$ & 21 \\
\hline $\begin{array}{l}\mathrm{As}(\mathrm{III}) \\
\mathrm{As}(\mathrm{V})\end{array}$ & $\mathrm{Al}-\mathrm{Fe}$ & $\begin{array}{l}8.3 \\
8.3\end{array}$ & $\begin{array}{l}3.7-4.6 \\
3.7-4.6\end{array}$ & $>99$ & 1 \\
\hline $\mathrm{Fe}$ & NA & 7.8 & NA & 98 & 21 \\
\hline $\mathrm{Ag}$ & NA & $2-6$ & NA & 20 to $<65$ & 45 \\
\hline $\mathrm{Au}$ & NA & $2-6$ & NA & 20 to $<50$ & 45 \\
\hline$U$ & NA & 3.52 & NA (10 passes) & 85 & 44 \\
\hline
\end{tabular}

NA-Not available. 
improve metal ion removal along with current density. The removal efficiency increases with an increase in current density, electrode dissolution rate and ultimately bubble and flocs production increases. A presence of higher amount of coagulants would increase electrical conductivity and precipitation feasibility, while it would enhance electrical energy requirement. Hence there is need for optimization of electrical conductivity, electrode geometry, current density, solution parameters, $\mathrm{pH}$, and other parameters for efficient removal of heavy metals [43]. e.g. $\mathrm{Cu}, \mathrm{Cr}$, $\mathrm{Ag}$ and $\mathrm{Au}$ showed higher removal efficiency at $\mathrm{pH} 6$ than 2; it might be due to higher size flocs formed [45].

This method is simple and inexpensive. It is fast and eco-friendly, as the separation is without addition of chemicals, which reduces sludge formation. The electrochemical methods require high initial capital investment, expensive electric supply. Separated material needs further treatment and has recovery or disposal issues. Apart from this, electrodes need to be cleaned or replaced periodically as there are chances of formation of oxide film on electrode which resists electric current [43]

In short, these conventional processes have their own separation conditions and must be optimized for separation of each ion separately depending upon solution concentration and composition. They have limitations like chemical consumption, low efficiency, incomplete or partial separation, high-energy requirements, production of hazardous sludge, need for recovery and disposal issues. It affects their applicability during real-life issues. Hence arises need for hybrid processing or advanced processes for heavy metal separation.

\section{Advanced Processes for Heavy Metal Separation}

A large amount of research is targeted towards separation of heavy metals. Various separation processes are being studied and evolved for improvement in separation efficiency. Hybrid processes are being tried for process modifications. Currently, the focus is on separation and recovery of heavy metals. The use of membrane-based separations is one of the important ways where physical separations can be used for separation and recovery of heavy metals. The heavy metals are recovered in pure form and can be utilized in further applications.

\section{Membrane Separation}

Membrane separation works on physical separation without addition of chemicals, which makes separation and recovery of components feasible. The benefits of membrane-based separation processes are easy operation, space-saving and high efficiency, further membrane properties can be tuned to provide desired transport properties. Its efficiency depends upon system design, choice, operation, and operating parameters. The membrane-based processes can be used for continuous separation and recovery of components. These processes can be combined with other processes in industry in an effluent plant. They can be operated under mild conditions, need low energy (comparing secondary treatment) and linear upscaling is possible.

Membranes are semipermeable barrier layers that leads to selective transport of components. The process streams are separated into permeate and retentate phase. The product of interest from given system is either retentate or permeate or both based upon composition of effluent and their concentrations. In case of water containing heavy metals as feed, retentate is heavy metals and permeate is purified water, which can be used in further applications. Different membranes process viz. reverse osmosis (RO), Nanofiltration (NF), Electrodialysis and Ultrafiltration are commonly used in heavy metal separation.

\subsection{Reverse Osmosis (RO)}

It works on reversal of osmosis using external pressure in the range of 20 to 100 bar [51]. Solvent passes through the semipermeable membrane retaining dissolved heavy metal salts [46]. RO is one of the largely commercialized membrane processes and popular method for water desalination [1]. The summery of different metal separation are given in Table 7.

Separation properties of $\mathrm{RO}$ are dependent upon solution properties, their composition, concentrations of components, $\mathrm{pH}$, driving force, operating parameters, and membrane properties. Issues of concentration polarization, along with higher metal rejection at higher metal concentrations are reported [47]. The decrease in rejection and increase in flux at higher driving pressure was observed due to the co-transport of salt molecules and possible effect of pressure on microstructure. Maximum retention of $\mathrm{Cr}, \mathrm{Cu}$ and $\mathrm{Ni}$ was observed at neutral [47] or alkaline $\mathrm{pH}$ [21]. It is because metal ions form complex with $\mathrm{OH}^{-}$ions, which affects the transport and rejection properties of metal ions. 
Table 7: Reverse Osmosis (RO) and its Application for Heavy Metal lons Removal

\begin{tabular}{|c|c|c|c|}
\hline Metal ion & Operating Parameters & Removal Efficiency (\%) & References \\
\hline $\mathrm{Cu}^{2+}$ & $\begin{array}{c}\text { atm } \\
\mathrm{pH}: 3-7 \\
3.5 / 4.5 \text { bar, } \mathrm{pH}: 3-7 \\
100 \text { or } 500 \text { bar } \\
3.5 \text { bar, pH 3-9 }\end{array}$ & $\begin{array}{c}99.5 \\
98-99 \\
98.75-99.71 \\
97.4-99.6 \\
98.83-99.9\end{array}$ & $\begin{array}{c}1 \\
47 \\
21\end{array}$ \\
\hline $\mathrm{Ni}^{2+}$ & $\begin{array}{c}\mathrm{pH}: 3-7 \\
3.5 / 4.5 \text { bar, } \mathrm{pH}: 3-7 \\
5 \mathrm{~atm} \\
8 / 100 / 500 \text { bar } \\
3.5 \text { bar, pH 3-9 }\end{array}$ & $\begin{array}{c}98-99 \\
98.12-99.23 \\
99.5 \\
97.3-99.5 \\
98.88-99.9\end{array}$ & $\begin{array}{c}47 \\
1 \\
48 \\
21\end{array}$ \\
\hline $\mathrm{Cr}$ & $\begin{array}{c}\mathrm{pH}: 3-7 \\
3.5 / 4.5 \text { bar, } \mathrm{pH}: 3-7 \\
100 / 500 \text { bar } \\
3.5 \text { bar, } \mathrm{pH} \text { 3-9 }\end{array}$ & $\begin{array}{c}95-99 \\
95.02-99.91 \\
98.3-100 \\
\approx 99.01\end{array}$ & $\begin{array}{l}47 \\
21\end{array}$ \\
\hline $\mathrm{Zn}^{2+}$ & 11 bar & 98.9 & 48 \\
\hline
\end{tabular}

NA-Not available.

RO membranes can withstand high temperature and have high rejection rate. This process is energyintensive due to high pressure (20-100 bar) operation [35]. It is mostly applicable to treat dilute solutions [49]. Apart from this RO removes a few healthy minerals including calcium and magnesium from water and restricts to pass mono-valent ions like $\mathrm{Na}^{+}, \mathrm{Cl}^{-}$etc. These are essential elements for normal growth of human [50]. Further presence of contaminants like chlorine, dissolved oxygen damages membranes and restrict their applicability [50].

\subsection{Nanofiltration (NF)}

Nanofiltration works at operating conditions intermediate between $\mathrm{RO}$ and UF. Pore size for NF membranes is around $1-10 \mathrm{~nm}$ and operating pressure is in the range of $5-20$ bar $[21,51]$. The separation efficiency is dependent upon parameters such as $\mathrm{pH}$, temperature etc. Increase in heavy metal removal efficiency with an increase in $\mathrm{pH}$ and a decrease in temperature is reported [1]. The process can be utilized for removal of divalent ions, salts, viruses, and organic molecules with molecular weight higher than $200 \mathrm{Da}$ [52]. The separation efficiency of NF membrane is shown in Table 8.

A higher salt rejection is observed at higher pressure [54]. Lower rejection at low pressure and high feed concentration can be attributed to high diffusive transport compared to convective transport. Higher rejection of copper ion by NF at 20 bar than when RO and NF are used combinedly at 35 bar is reported [1]. This could be attributed to the increased convective transport of salts with water molecules at higher pressure across the membranes. Further, the hydrodynamic diameter of salt molecules affects largely separation efficiency as seen from lower rejection of $\mathrm{Cd}$ $\left(\mathrm{CdCl}_{2}\right)$ compared to $\mathrm{Ni}\left(\mathrm{NiSO}_{4}\right)$. Rejection of $\mathrm{As}^{3+}$ is much lesser than $\mathrm{As}^{5+}$ due to higher diffusivity of former attributed to its lower hydrodynamic diameter compared to later.

The rejection was increased with feed flow rate due to reduction in concentration polarisation at membrane surface and increase in mass transfer coefficient. Azimi A. et al.2017 reported an increase in $\mathrm{Ar}, \mathrm{Cr}$ rejection with an increase in feed concentration from 100 to 400 $\mathrm{ppb}$, while the effect is nil on $\mathrm{Pb}$ rejection with an increase in feed concentration from 5 to $250 \mathrm{mg} / \mathrm{L}$. Both these properties can be attributed to molecular properties and increase in concentration polarisation at membrane. The $\mathrm{pH}$ of solution has a large effect on hydration of molecules, complex formation, and charge properties of molecules [53] Higher rejection for $\mathrm{As}^{3+}$ at $\mathrm{pH} 11$ compared to $\mathrm{pH} 8$ are reported for H_PAMAM G2 and H_TFC membranes. This can be attributed to an increase in negative charge on salts at higher $\mathrm{pH} 11$ as compared to $\mathrm{pH} 9$. Such charge on salt components would lead to higher rejection by Donnan exclusion principle. In case of salts without any effect of $\mathrm{pH}$ on complex formation, the effect of variation in $\mathrm{pH}$ (1.5 to 7 ) would not have any effect on salt rejection. The same has been reported in case of $\mathrm{Zn}$ rejection at 
Table 8: Heavy Metal lons Removal using Nanofiltration (NF)

\begin{tabular}{|c|c|c|c|c|}
\hline Metal Ion & Membrane & $\mathrm{pH}$ & (\%)Removal Efficiency & References \\
\hline $\mathrm{Cu}(\mathrm{II})$ & $\begin{array}{c}\text { RO+UF: } 35 \text { bar } \\
\text { H_PAMAM G2,H_TFC }\end{array}$ & $\begin{array}{c}20-35 \text { bar } \\
10 \text { bar, pH: } 4.6\end{array}$ & $\begin{array}{c}95-98 \\
>99\end{array}$ & $\begin{array}{l}43 \\
53\end{array}$ \\
\hline $\mathrm{Ni}(I I)$ & $\begin{array}{c}\text { NA } \\
\text { H_PAMAM G2, H_TFC }\end{array}$ & $\begin{array}{c}\text { 12-20bar, pH: } 1-9 \\
10 \text { bar }\end{array}$ & $\begin{array}{c}80-98.90 \\
>99.21\end{array}$ & $\begin{array}{c}54.21 \\
53\end{array}$ \\
\hline $\begin{array}{l}\mathrm{As}^{3+} \\
\mathrm{As}^{5+}\end{array}$ & $\begin{array}{l}\text { H_PAMAM G2, H_TFC } \\
\text { H_PAMAM G2, H_TFC } \\
\text { H_PAMAM G2, H_TFC } \\
\text { H_PAMAM G2, H_TFC }\end{array}$ & $\begin{array}{r}\mathrm{pH}: 8 \\
\mathrm{pH}: 11 \\
\mathrm{pH}: 8 \\
\mathrm{pH}: 11\end{array}$ & $\begin{array}{c}83.12-88.13 \\
97.60-97.89 \\
>99 \\
97.89-99.81\end{array}$ & 53 \\
\hline $\mathrm{Cd}(\mathrm{II})$ & $\begin{array}{c}\text { NA } \\
\text { H_PAMAM G2, H_TFC }\end{array}$ & $\begin{array}{l}20 \text { bar, } \mathrm{pH}: 1-9 \\
10 \text { bar, } \mathrm{pH}: 4.8\end{array}$ & $\begin{array}{l}80-97.26 \\
>99\end{array}$ & $21,53,54$ \\
\hline $\mathrm{Pb}(\mathrm{II})$ & $\begin{array}{c}\text { NA } \\
\text { H_PAMAM G2, H_TFC }\end{array}$ & $\begin{array}{c}25-30 \text { bar, } \mathrm{pH}: 5.8 \\
10 \text { bar, } \mathrm{pH}: 5\end{array}$ & $\begin{array}{l}>99 \\
>99\end{array}$ & $\begin{array}{l}21 \\
53\end{array}$ \\
\hline $\mathrm{Ar}$ & NA & $\mathrm{pH}: 7.1,14$ bar & 97 & 21 \\
\hline $\mathrm{Cr}$ & $\begin{array}{c}\text { NA } \\
\text { H_PAMAM G2, H_TFC }\end{array}$ & $\begin{array}{c}\mathrm{pH}: 7.1,14 \text { bar } \\
10 \text { bar }\end{array}$ & $\begin{array}{c}95 \\
98.21-99.11 \\
\end{array}$ & $\begin{array}{l}21 \\
53\end{array}$ \\
\hline $\mathrm{Zn}(\mathrm{II})$ & $\begin{array}{c}\text { NA } \\
\text { NA } \\
\text { H_PAMAM G2,H_TFC }\end{array}$ & $\begin{array}{l}\mathrm{pH}: 7,30 \text { bar } \\
\mathrm{pH}: 1.5,30 \text { bar } \\
10 \text { bar }\end{array}$ & $\begin{array}{c}95-99 \\
95 \\
>99\end{array}$ & $\begin{array}{l}55 \\
53\end{array}$ \\
\hline $\mathrm{CaCl}_{2}$ & $\begin{array}{l}\text { NF200 } \\
\text { NF90 }\end{array}$ & $\begin{array}{l}45^{\circ} \mathrm{C}, \mathrm{pH} 3-10 \\
45^{\circ} \mathrm{C}, \mathrm{pH} 3-10\end{array}$ & $\begin{array}{c}50-65 \\
>97\end{array}$ & 56 \\
\hline $\mathrm{NaCl}$ & $\begin{array}{l}\text { NF90 } \\
\text { NFX } \\
\text { NFG }\end{array}$ & $\begin{array}{c}45^{\circ} \mathrm{C}, \mathrm{pH} 3-10 \\
50^{\circ} \mathrm{C}, \mathrm{pH} 3-10.5 \\
45^{\circ} \mathrm{C}, \mathrm{pH} 4-10\end{array}$ & $\begin{array}{c}85-95 \\
40 \\
10\end{array}$ & 56 \\
\hline $\mathrm{MgSO}_{4}$ & $\begin{array}{c}\text { NFX } \\
\text { HL and DK } \\
\text { CK } \\
\text { NFG }\end{array}$ & $\begin{array}{c}50^{\circ} \mathrm{C}, \mathrm{pH} 3-10.5 \\
50^{\circ} \mathrm{C}, \mathrm{pH} 3-9 \\
30^{\circ} \mathrm{C}, \mathrm{pH} 5-6.5 \\
50^{\circ} \mathrm{C}, \mathrm{pH} 4-10\end{array}$ & $\begin{array}{l}99 \\
98 \\
94 \\
50\end{array}$ & 56 \\
\hline
\end{tabular}

NA-Not applicable, PAMAM-polyamidoamine membrane, H_TFC (thin film composite).

constant concentration (1200 ppm) and pressure (30 bar) [55]. Also, at low metal ion concentration (60 ppm) rejection is more than at $1200 \mathrm{ppm}$ by maintaining same pressure and $\mathrm{pH}$. This is because of low concentration polarization. This would not provide the repulsive charge ion layer on the surface of membrane and reduce the retention properties.

The process has energy benefits compared with RO but it has issues for removal of soluble elements [51]. Moreover, it removes divalent ions, $\mathrm{Ca}^{+2}$ and $\mathrm{Mg}^{+2}$ from water which are essential ions for humans.

\subsection{Electrodialysis}

It works on electric field as a driving force using cation-exchange or anion-exchange membranes. The ions are transported across charged membranes under the influence of electric current. Separation efficiency is increased with an increase in voltage and temperature and with a decrease in the flow rate of fluid to be separated [49]. High flow rate results in low residence time resulting in lower separation efficiency. The performance of electrodialysis membrane depends on the operating parameter and type of cell used. It requires feed to be free from sediments or floating particles. It is not suitable for separation of high molecular weight ionic components [49]. Table 9 gives separation details using ED.

Separation is also affected largely by temperature due increase in ionization, diffusivity increases the electrical charge transport and conductivity at higher temperature. Whereas separation efficiency decreases with an increase in the flow rate as ions will not get enough time for separation. The separation is adversely affected by an increase in flow rate and concentration polarization of solutions. An increase in flow rate would affect the ionization properties and 
Table 9: Heavy Metal lons Removal using Electrodialysis (ED)

\begin{tabular}{|c|c|c|c|c|c|c|}
\hline Metal Ion & Membrane & Initial Metal lon Concentration & $\begin{array}{l}\text { Voltage } \\
\text { (V) }\end{array}$ & $\begin{array}{l}\text { Time } \\
\text { (min) }\end{array}$ & $\begin{array}{c}\text { Removal } \\
\text { Efficiency (\%) }\end{array}$ & References \\
\hline $\mathrm{Pb}(\mathrm{II})$ & $\begin{array}{l}\text { (AR204SXR412) and } \\
(\text { CR67,MK111) }\end{array}$ & $\begin{array}{c}100-500 \text { ppm(flow rate: } \\
0.07 \mathrm{~mL} / \mathrm{s}), 25-60^{\circ} \mathrm{C}\end{array}$ & $10-30$ & NA & 20- 90 & 49 \\
\hline $\mathrm{NaCl}-\mathrm{SO}_{4}$ & $\begin{array}{l}\text { ACS/CMS } \\
\text { AMV/CMV }\end{array}$ & $\mathrm{mmol} / \mathrm{L}$ & 5 & $\begin{array}{c}5-35 \\
15-40\end{array}$ & $\begin{array}{l}30-35 \\
20-30\end{array}$ & 52 \\
\hline $\mathrm{MgCl}-\mathrm{SO}_{4}$ & $\begin{array}{l}\text { ACS/CMS } \\
\mathrm{AMV} / \mathrm{CMV}\end{array}$ & $0.01 \mathrm{mmol} / \mathrm{L}$ & 5 & $\begin{array}{c}15-30 \\
\geq 5\end{array}$ & $\begin{array}{c}\approx 10 \\
1\end{array}$ & 52 \\
\hline $\mathrm{NaCl}-\mathrm{MgCl}$ & $\begin{array}{l}\text { ACS/CMS } \\
\text { AMV/CMV }\end{array}$ & $0.01 \mathrm{mmol} / \mathrm{L}$ & 5 & $\begin{array}{l}5-35 \\
5-20\end{array}$ & $\begin{array}{l}50-70 \\
30-40\end{array}$ & 52 \\
\hline $\begin{array}{l}\mathrm{NaSO}_{4-}^{-} \\
\mathrm{MgSO}_{4}\end{array}$ & $\begin{array}{l}\text { ACS/CMS } \\
\mathrm{AMV} / \mathrm{CMV}\end{array}$ & $0.01 \mathrm{mmol} / \mathrm{L}$ & 5 & $\begin{array}{l}5-35 \\
\approx 35\end{array}$ & $\begin{array}{l}10-50 \\
\approx 10\end{array}$ & 52 \\
\hline
\end{tabular}

NA-Not applicable.

conductivity of solution which would reduce separation efficiency. The concentration polarization results in formation of an ionic double layer on membrane surface. This would enhance membrane resistance and adversely affect transport properties.

Bruggen B.V. D. et al. 2004 has done ED experiments using ACS/CMS and AMV/CMV membranes at $5 \mathrm{~V}$ for $\mathrm{NaCl}-\mathrm{SO}_{4}, \mathrm{MgCl}-\mathrm{SO}_{4}, \mathrm{NaCl}-$

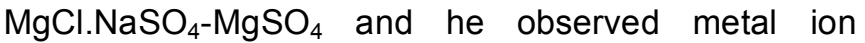
rejection is higher for ACS/CMS membrane than AMV/CMV membranes. This might be because AMV/CMV membranes have least mass transport resistance. The process has issues of high operating and maintenance costs.

\subsection{Ultrafiltration}

Ultrafiltration membranes work on sieving mechanism combined with Knudsen flow system at low trans-membrane pressure of 1-5 bar and can work up to 10 bar. The pore size of UF membranes ranges from 20-100 nm [51]. Therefore, it restricts the flow of viruses, DNA, vitamin, and proteins. They have benefits of low energy consumption as compared to $\mathrm{RO}, \mathrm{NF}$ or ED and ease of upscaling. The membranes can be modified to provide surface charge and applied in the separation of heavy metals by Donnan Exclusion principle [1].

\section{Micellar Enhanced Ultrafiltration (MEUF):} Separation is supported and carried out with addition of surfactant. These surfactants form complexes with heavy metals. These resulted in complexes with larger size and hydrodynamic diameter can be separated by sieving mechanism using ultrafiltration membranes.
Separation is dependent on type and concentration of surfactants used. Additionally, the complex formation efficiency of surfactant is dependent upon charge, interaction ability and surface properties of surfactant. The separation efficiency of membrane is based on surface properties of membrane, its pore size, porosity, and concentration, composition and $\mathrm{pH}$ of feed to be treated $[57,58]$. The quantity or concentration of surfactant above which micelles are formed is called critical micelle concentration (CMC) [57]. It is observed that surfactants having charge opposite to ions show better complex formation and high retention [58]. The process requires regeneration of surfactant and direct application of recovered metal in further processes is not possible [1].

Polymer Enhanced Ultrafiltration (PEUF): This technique is also called polymer assisted ultrafiltration (PAUF), polymer-supported ultrafiltration (PSU), liquidphase polymer-based retention (LPR), enhanced ultrafiltration (EUF) or simply polymer filtration (PF) [59]. Heavy metal ions are separated by combining with the water-soluble polymer which forms complexes. These complexes are larger in size and possess higher hydrodynamic diameter. Thus, they can be separated by sieving mechanism using ultrafiltration membranes [60]. The commonly reported complexing agents are Polyacrylic acid (PAA), polyethyleneimine (PEI), diethylaminoethyl cellulose, humic acid, chitosan, pectin etc. $[10,60]$. They possess high separation efficiency due to better binding capacity with metal ions. The downstream is requires for separation of heavy metal ions and regeneration of polymer. This restricts direct use of recovered metal. Table $\mathbf{1 0}$ shows separation by UF membranes. 
Table 10: Heavy Metal lons Removal using Ultrafiltration (MEUF/PEUF)

\begin{tabular}{|c|c|c|c|c|c|}
\hline Metal Ion & UF Type & Membrane / Surfactant or Complexing Agent & pH & $\begin{array}{l}\text { \% Removal } \\
\text { Efficiency }\end{array}$ & References \\
\hline $\mathrm{Zn}(\mathrm{II})$ & $\begin{array}{l}\text { PEUF } \\
\text { MEUF }\end{array}$ & $\begin{array}{l}\text { PES-10, PES-20 / PEI-25/70 or PAA } \\
\text { CAC- } 40 \text { / PEI- } 25 \text { or } 70 \\
\text { CAC- } 40 \text { / PAA } \\
\text { PES-100 / PEI- } 25 \text { or } 70 \text { or PAA } \\
\text { PS /SDS } \\
\text { Cellulose }\end{array}$ & $\begin{array}{c}7-8 \\
7-8 \\
7 \\
7-8 \\
\text { NA } \\
\text { NA }\end{array}$ & $\begin{array}{l}62-89 \\
\approx 63 \\
92.1 \\
60-76 \\
92-98 \\
99\end{array}$ & $\begin{array}{c}61 \\
1\end{array}$ \\
\hline $\mathrm{Pb}(\mathrm{II})$ & $\begin{array}{l}\text { MEUF } \\
\text { UF }\end{array}$ & $\begin{array}{l}\text { Ceramic /Dodecylbenzenesulfonic acid, Dodecylamine } \\
\text { PS-CNT(amide treated)0-1 \%CNT, 20-100\% PS }\end{array}$ & $\begin{array}{c}7.47 \\
2.6\end{array}$ & $\begin{array}{c}>99 \% \\
10.5-90.1\end{array}$ & $\begin{array}{c}1 \\
62\end{array}$ \\
\hline $\mathrm{Cd}(\mathrm{II})$ & $\begin{array}{l}\text { PEUF } \\
\text { MEUF } \\
\text { UF }\end{array}$ & $\begin{array}{l}\text { PS / PolyammoniumAcrylate } \\
\text { PS /SDS } \\
\text { Cellulose } \\
\text { PS/CNT(amide treated)0-1 \%CNT, } 20-100 \% \text { PS }\end{array}$ & $\begin{array}{l}6.32 \\
\text { NA } \\
\text { NA } \\
2.6\end{array}$ & $\begin{array}{c}99 \\
92-98 \\
99 \\
9.9-78\end{array}$ & $\begin{array}{c}1 \\
62\end{array}$ \\
\hline $\mathrm{Ni}(I I)$ & $\begin{array}{l}\text { MEUF } \\
\text { PEUF }\end{array}$ & $\begin{array}{l}\text { PC/ Sodium lauryl ether sulfate } \\
\text { Iris 10, Iris } 30 \text { / PEI } \\
\text { Polyethersulfone / PEI, CarboxyMethyl-Cellulose }\end{array}$ & $\begin{array}{c}7 \\
2-4 \\
7-8\end{array}$ & $\begin{array}{c}98.6 \\
92-100 \\
99-100\end{array}$ & $\begin{array}{c}1 \\
63\end{array}$ \\
\hline $\mathrm{Cu}(\mathrm{II})$ & $\begin{array}{l}\text { PEUF } \\
\text { UF }\end{array}$ & $\begin{array}{l}\text { Polyethersulfone/ PEI, CarboxyMethyl-Cellulose } \\
\text { Ceramic / Polyacrylic acid } \\
\text { Iris } 10 \text {,Iris } 30 \text { /PEI } \\
\text { PS-CNT(amide treated)0-1 \%CNT, } 20-100 \% \text { PS }\end{array}$ & $\begin{array}{l}6-7 \\
5.5 \\
2-4 \\
2.6\end{array}$ & $\begin{array}{l}94-97.6 \\
99.5 \\
93-100 \\
10.1-93\end{array}$ & $\begin{array}{l}1 \\
63 \\
62\end{array}$ \\
\hline $\begin{array}{l}\mathrm{Cr}(\mathrm{II}) \\
\mathrm{Cr}(\mathrm{VI}) \\
\mathrm{Cr}(\mathrm{III})\end{array}$ & $\begin{array}{l}\text { PEUF } \\
\text { PEUF } \\
\text { UF }\end{array}$ & $\begin{array}{l}\text { Polyethersulfone / Carboxy methyl cellulose } \\
\text { SodiumPolyacrylate,PEI } \\
\text { AMICON } 8400 \\
\text { PAN } \\
\text { PS-CNT(amide treated)0-1 \%CNT, 20-100\% PS } \\
\text { NA } \\
\text { NA }\end{array}$ & $\begin{array}{c}7 \\
5-6 \\
\text { NA } \\
2.6 \\
5-6 \\
7-10\end{array}$ & $\begin{array}{c}99.5 \\
82-100 \\
45-96 \\
10.2-94 \\
50-75 \\
90-95\end{array}$ & $\begin{array}{c}1 \\
7 \\
62\end{array}$ \\
\hline $\begin{array}{l}\text { As }(I I I) \\
\text { As }(\mathrm{V})\end{array}$ & UF & $\begin{array}{l}\text { PS-CNT(amide treated)0-1 \%CNT, } 20-100 \% \text { PS } \\
15 \% \mathrm{PS}, 0-2 \% \mathrm{GO}\end{array}$ & 2.6 & $\begin{array}{c}10.9-80 \\
25.87-84\end{array}$ & $\begin{array}{l}62 \\
64\end{array}$ \\
\hline
\end{tabular}

PS-Polysulfone, PES-Polyether sulfone, PC-Polycarbonate, SDS-sodium dodicylesulfate, PEI-Polyethyleneimine,GO-Graphene oxide, PANPolyacrylonitrile, NA-Not available.

Separation efficiency increases from $90-100 \%$ with an increase in micellar (SDS) concentration to above $\mathrm{CMC}$ for $\mathrm{Pb}, \mathrm{Cd}$ and $\mathrm{Zn}[1]$. The same properties are reported for separation of heavy metal ions using polymers like $\mathrm{PEI}$, polyammonium acrylate, polyacrylic acid etc. The complex is formed by PEI at pH 6 and 8 with the weight ratio of polymer to metal ion as 3 and 6 for optimum rejection of $\mathrm{Cu}$ and $\mathrm{Ni}$ [63]. An alkaline $\mathrm{pH}$ is required for $\mathrm{Cr}(\mathrm{III})$ for optimum rejection properties $\mathrm{PEI}$, chitosan and pectin polymer. The maximum rejection of $\mathrm{Ni}$ for Iris $10 \mathrm{kDa}$ membrane is reported at $\mathrm{PEI} / \mathrm{Ni}$ weight ratio of 6 . It might be attributed to higher binding of $\mathrm{PEI}$ with $\mathrm{Ni}$ [63]. Such binding would increase the complex size and results in higher hydrodynamic diameter results in higher removal.

Surface and the interactive properties of membranes is another important point in retention properties for various molecules. The rejection properties for $\mathrm{Cu}$ are higher in Iris 10 as compared to Iris 30 , while opposite is observed for $\mathrm{Ni}$ [63]. A better rejection at 2 bar than 4 is reported [63]. This can be attributed to variation in hydrodynamic properties and co-transport of molecules at higher pressure. Borbely G. et al. 2009 studied rejection of $\mathrm{Zn}$ on different membranes namely PES-10, PES-20, CAc-40, PES100 having molecular weight cut off 10,20,40 and 100 $\mathrm{kDa}$ respectively. Different polymers like PEI-25 (molecular weight (MW)-25000), PEI-70 (MW-70000), PAA (MW-not specified) are used as complexing agents and solution $\mathrm{pH}$ was maintained at 7 and 8 . It is observed that at $\mathrm{pH} 7$, the rejection using PES-20 and PES-100 membranes with PEI-70 complexing agent is comparatively better than at $\mathrm{pH} 8$. This could be attributed to higher complexing and interactive properties of $\mathrm{Zn}$ at $\mathrm{pH}$ 7. An opposite retention property is reported with CAc-40 membrane [61]. All these observations underline that properties of membranes 
and their interactions with heavy metals and complexes are highly essential when material transport, separation properties are being considered.

As seen from Table 10 MEUF and PEUF have high separation efficiency for heavy metals but they require addition of chemicals (surfactant or polymer) to bind metal ions. Such chemical addition results in formation of a complex with a surfactant or polymeric agent. The heavy metals are separated into complex form. It requires regeneration of chemicals and direct use of metal ions is not possible due to separation in complex formation and presence of impurities. Hence instead of MEUF and PEUF simple UF with charged surface can be used for separation of metal ions.

The separation of UF membranes is based upon a sieving mechanism. Such separation is dependent upon membrane properties, pore size and hydrodynamic diameter of particles. In case of heavy metals, the hydrodynamic diameters of single molecules are small as compared to the pore size of UF membranes. Hence there is a need for the improvement of membrane surface properties which would retain the heavy metals by the Donnan exclusion principle. Here membranes are prepared by grafting or modification of the surface by chemical interaction.

Membrane modification by grafting was well reported by Hernández-Aguirre O. A. et al. 2016. He modified the polypropylene membrane by grafting biopolymer-potato starch, chitosan, cellulose, acrylic acid, and benzophenone. Grafting depends on reaction time and concentration. The resulting membrane shows hydrophilicity- which in turn reduces fouling. Metal ion removal was observed to be more than $95 \%$ for $\mathrm{Cu}, \mathrm{Ni}$, and $\mathrm{Cr}$ for polyethyleneimine grafted membrane [66]. This post membrane synthesis modification process alters membrane properties and affects membrane stability.

Another method can be physical blending of polymer or charged compounds for surface charges. This results in the separation of metal ions by Donnan exclusion. From the literature survey, it is observed that formation of UF membrane using physical blending is the best method for heavy metal ion separation. Membrane properties are improved for rejection properties of heavy metal ions by different methods such as use of additives, porogen agent, surface modification, chemical modification etc. has reported $[62,64]$. Further, the operating conditions are highly important while controlling transport and rejection properties. A decrease in rejection with an increase in feed solution concentration is reported. Muthumareeswaran M.R. et al. 2017 observed that with an increase in solution concentration, rejection has decreased. This is because of concentration polarization effect on membrane at high concentration of 400 PPM, whereas at low concentration of 0.25 and 25 PPM rejection is same.

At constant pressure and varying velocity, rejection increases due to reduction in the concentration polarization at membrane. An increase in reduction is reported at higher pressure [7]. Charge on membrane surface and metal ions, their ionization and solution $\mathrm{pH}$ also have a strong effect on the rejection properties. The $\mathrm{pH}$ of solution affects the rejection properties to a greater extent. It affects ionization and salvation of metals] ions, changing their removal efficiency. e.g. chromium (hexavalent) exists in different forms such as chromate $\left(\mathrm{CrO}_{4}{ }^{2-}\right)$, dichromate $\left(\mathrm{Cr}_{2} \mathrm{O}_{7}{ }^{2-}\right)$, hydrogen chromate $\left(\mathrm{HCrO}_{4}^{-}\right)$, hydrogen dichromate $\left(\mathrm{HCr}_{2} \mathrm{O}_{7}\right)$ and chromic acid $\left(\mathrm{H}_{2} \mathrm{CrO}_{4}\right)$ at different $\mathrm{pH}$. This affects the rejection properties strongly along with membrane properties. Rezaee R. et al. 2015 studied arsenate rejection using polysulfone-graphene oxide (GO) membrane with variable $\mathrm{GO}$ concentration (from 0 to 2 $\%)$. It is observed that arsenate rejection is maximum when GO weight \% is 2 compare with pure polysulfone membranes and membranes with $0.5,1$ and $1.5 \% \mathrm{GO}$. This is because presence of negatively charged hydroxyl and carboxylic group in GO introduce a negative charge to membrane surface. According to Donnan exclusion/ repulsion, it increases rejection. Also, same as Rezaee R et al. 2015, Amira A. A. et al. 2015 studied rejection of different metal ions using PS membrane with varied MWCNT concentration. He also obtained the same result, with an increase in CNT \%, metal ion rejection increases.

During the formation of polymeric membranes by phase inversion, it is desired to have an optimum molecular weight cut off (MWCO) and maximum output (flux) with better selectivity [67]. The MWCO depends upon pore size of membrane. MWCO is lowered with reduction in pore size [62]. The pore size can be optimized by varying membrane preparation and dope solution concentration [68]. For lower MWCO, higher dope solution concentration is required. In the process of formation of membrane with high dope solution concentration, pure water flux gets reduced, that is transport rate properties decreased $[68,62]$. So, there is a need to optimize membrane properties with desired flux-transport property and selectivity characteristics. 
Table 11: Advantages / Limitations of Different Separation Processes for Heavy Metal Separation

\begin{tabular}{|c|c|c|c|}
\hline Sr. No. & Separation Method & Advantages & Limitations \\
\hline 1. & Chemical Precipitation & Simple, inexpensive, low capital cost & $\begin{array}{l}\text { Less effective under low concentration, large amount of } \\
\text { sludge produced, disposal / retreatment problem }\end{array}$ \\
\hline $1 \mathrm{~A}$. & Hydroxide precipitation & Simple, low cost, ph control easy & $\begin{array}{l}\text { Generates large volume of low density sludge,sludge is } \\
\text { difficult to process, dewatering and disposal problem }\end{array}$ \\
\hline $1 \mathrm{~B}$. & Sulfide precipitation & $\begin{array}{l}\text { Broad ph range, better thickening } \\
\text { dewatering characteristics }\end{array}$ & $\begin{array}{l}\text { Higher cost for sludge production / disposal,poor } \\
\text { settling,slow precipitation, in acid condition evolves toxic } \mathrm{H}_{2 \mathrm{~S}} \\
\text { fumes. }\end{array}$ \\
\hline $1 \mathrm{C}$. & $\begin{array}{l}\text { Chemical precipitation } \\
\text { with Electro-Fenton } \\
\text { process }\end{array}$ & Requires strong acidic condition & $\begin{array}{l}\text { Higher removal efficiency, lower energy consumption, } \\
\text { economical, efficient, environmental friendly }\end{array}$ \\
\hline 2. & Ion exchange & High removal efficiency, fast kinetics & $\begin{array}{l}\text { Expensive process, secondary pollution-resin regeneration, } \\
\text { metal ions disposal / recovery problem }\end{array}$ \\
\hline 3 & Adsorption & $\begin{array}{l}\text { Low cost, wide ph range, good removal } \\
\text { capacity, easy operating conditions }\end{array}$ & $\begin{array}{l}\text { Low selective, efficiency depends on adsorbent properties, } \\
\text { disposal and regeneration issues. }\end{array}$ \\
\hline $4-A, B$ & $\begin{array}{l}\text { Coagulation and } \\
\text { Flocculation }\end{array}$ & $\begin{array}{l}\text { Removes turbidity, sludge settles quickly, } \\
\text { good settling/ dewatering characteristics }\end{array}$ & $\begin{array}{l}\text { Produces large volume of sludge, } \\
\text { Requires extra cost for sludge disposal, } \\
\text { Regeneration/ recovery issues }\end{array}$ \\
\hline $4-\mathrm{C}$ & Flotation & $\begin{array}{l}\text { Low cost of operation, good separation } \\
\text { efficiency, produce concentrated sludge }\end{array}$ & High capital cost, high maintenance cost, high operation cost \\
\hline 5 & Electrochemical & $\begin{array}{l}\text { No additional chemical is required, } \\
\text { simple, fast, easy to operate, eco-friendly }\end{array}$ & $\begin{array}{l}\text { High initial capital investment, expensive electric supply, } \\
\text { recovery/ disposal issue }\end{array}$ \\
\hline $5-\mathrm{A}$ & Electro-Coagulation & $\begin{array}{l}\text { No additional chemical is required, } \\
\text { precipitate formed is stable, simple, fast, } \\
\text { easy to operate, eco-friendly }\end{array}$ & Expensive electric supply, recovery/ disposal issue \\
\hline $5-B$ & Electro-Floatation & $\begin{array}{l}\text { Treat dilute solutions, simple design and } \\
\text { operation, low operational cost }\end{array}$ & $\begin{array}{l}\text { Performance depend on-current density, ph, type of } \\
\text { electrode }\end{array}$ \\
\hline $5-\mathrm{C}$ & Electro-Deposition & $\begin{array}{l}\text { Do not produce sludge, } \\
\text { Selective separation }\end{array}$ & $\begin{array}{l}\text { Performance depend on-initial concentration, current density, } \\
\text { ph, temp. Of solution }\end{array}$ \\
\hline 6 & Membrane Process & $\begin{array}{l}\text { Require less space/ energy, separation } \\
\text { selectivity is high }\end{array}$ & $\begin{array}{l}\text { Operation cost is high, membrane fouling, permeate flux is } \\
\text { low }\end{array}$ \\
\hline $6-A$ & Reverse Osmosis & $\begin{array}{l}\text { Withstand high temperature, } \\
\text { High rejection rate }\end{array}$ & $\begin{array}{l}\text { Require high energy as process is carried out at high } \\
\text { pressure, not applicable for concentrated solutions, water } \\
\text { should be chlorine }\left(\mathrm{Cl}_{2}\right) \text { free or else it will damage } \\
\text { membrane, removes healthy minerals including calcium and } \\
\text { magnesium, membrane fouling }\end{array}$ \\
\hline $6-\mathrm{B}$ & Nano-filtration & $\begin{array}{l}\text { Removes divalent molecule, viruses, } \\
\text { salts, requires less energy in comparison } \\
\text { to RO }\end{array}$ & $\begin{array}{l}\text { Not suitable to separate soluble elements, removes } \mathrm{Ca}^{+2} \text { and } \\
\mathrm{Mg}^{+2} \text { ions, which are essential elements for human, costly, } \\
\text { membrane fouling }\end{array}$ \\
\hline $6-\mathrm{C}$ & Electrodialysis & $\begin{array}{l}\text { Performance is independent on the type } \\
\text { of ions, requires clean feed, periodic } \\
\text { maintenance, selective separation } \\
\text { process }\end{array}$ & $\begin{array}{l}\text { Performance depends on operating parameter, type of cell } \\
\text { used, method is not suitable to remove organic matter, } \\
\text { colloids and } \mathrm{sio}_{2} \text { and high molecular weight ionic components }\end{array}$ \\
\hline $6-\mathrm{D}$ & Microfiltration & $\begin{array}{l}\text { Relatively high flux/ low pressure, restrict } \\
\text { flow of bacteria, blood cells, starch, } \\
\text { pollens }\end{array}$ & $\begin{array}{l}\text { Heavy metals can easily pass, removes only suspended } \\
\text { particles and bacteria, sensitive to oxidative chemicals such } \\
\text { as nitric acid, sulphuric acid, peroxide and persulfate etc. }\end{array}$ \\
\hline $6-E$ & Ultrafiltration & $\begin{array}{l}\text { Require less space, less energy } \\
\text { consumption, up-scaling is easy, high } \\
\text { removal efficiency, remove viruses, DNA, } \\
\text { vitamin, albumin, remove dissolved and } \\
\text { colloidal material }\end{array}$ & Operation cost is high, membrane fouling \\
\hline $6-E-A$ & $\begin{array}{l}\text { Micellar Enhanced } \\
\text { Ultrafiltration (MEUF) }\end{array}$ & $\begin{array}{l}\text { High binding selectivity, high removal } \\
\text { efficiency }\end{array}$ & $\begin{array}{l}\text { Require addition of surfactants, require regeneration of } \\
\text { surfactants, direct use of metal is not possible, separation is } \\
\text { based on surface properties of membrane, its pore size and } \\
\text { porosity, concentration, ph of feed to be treated }\end{array}$ \\
\hline $6-E-B$ & $\begin{array}{l}\text { Polymer Enhanced } \\
\text { Ultrafiltration (PEUF) }\end{array}$ & Good separation efficiency & $\begin{array}{l}\text { Require addition of polymer to bind metal ions, needs } \\
\text { regeneration of polymer, direct use of metal is not possible. }\end{array}$ \\
\hline
\end{tabular}

Hence, simple UF overcomes limitations offered by conventional as well as advanced processes including
MEUF and PEUF. Table 11 describes the advantages, limitations of conventional and advanced processes. 


\section{CONCLUSION}

Safe water is life, but industrialization has caused contamination of water with many health issues. One of the major issues is the release of heavy metals through process waste and other effluent streams. They can be detrimental to health along with causing many illnesses. Hence WHO has given permissible limits of heavy metal ions in water as a part of strict environmental regulations.

Multiple separation options have been investigated for the separation of heavy metals. Up till now the major focus was on the removal of components and their disposal. It would result in the generation of a large amount of waste stockpile which needs further treatment for recovery of components or disposal. This would generate secondary waste. Hence there is a need to focus on the recovery of components in their nascent form without any chemical impurity addition. This can be done using membrane-based physical separation. Though various techniques are available, the NF and RO have their inherent issues of permeation limitations, high-pressure requirement, energy, and difficulty to design. In the case of ultrafiltration membranes efficient separation is feasible using micellar/ polymer enhanced UF. Though this separation is techno-economically feasible, it leads to an addition in impurities and change in chemical properties of the material to be separated. Hence there is a need to optimize the membrane properties for physical separation only. This can be feasible by preformation modification of membrane properties by addition of modification agents of post-formation by grafting or chemical treatment. Later treatment changes the chemical properties of the membrane surface and affects membrane stability. Hence the membrane modification by insertion of modifying agent (nanomaterial/ pore-forming agent etc.) while preparing the dope solution by physical blending is recommended. In short, pre-synthesis modification is preferred over post-synthesis methods like coating, grafting, etc. Such optimization of membrane formation to obtain desired transport and selective separation properties is highly desirable and a large work needs to be focused on this direction.

\section{DATA AVAILABILITY}

All data used during the study is appeared / available in the article and supplementary file.

\section{ACKNOWLEDGMENT}

We thank Bharati Vidyapeeth (Deemed to be) University College of Engineering, Pune and MIT-World Peace University, Pune for providing us the useful resources. We also thank for the financial support from DST- Nano Mission (Sanction No. SR/MN/NT/1029/2015).

\section{REFERENCES}

[1] Fu F, Wang Q. Removal of heavy metal ions from wastewaters: A review. J. Environ. Manage 2011, 92: 407418.

https://doi.org/10.1016/j.jenvman.2010.11.011

[2] Bessbousse H, Rhlalou T, Verchère JF, Lebrun L. Removal of heavy metal ions from aqueous solutions by filtration with a novel complexing membrane containing polyethyleneimine in a polyvinyl alcohol matrix. J. Membr. Sci. 2008; 3072: 249259.

https://doi.org/10.1016/j.memsci.2007.09.027

[3] Igwe JC, Abia AA. A bioseparation process for removing heavy metals from waste water using biosorbents. Afr. J. Biotechnol 2006; 5: 1167-1179.

[4] Hubicki Z, Kolodynska D. Selective Removal of Heavy Metal lons from Waters and Waste Waters Using Ion Exchange Methods. Ion Exch. Technol. 2012; 193-240. https://doi.org/10.5772/51040

[5] Bellinger DC. Lead Contamination in Flint - An Abject Failure to Protect Public Health. N. Engl. J. Med. 2016; 37412: 11011103.

https://doi.org/10.1056/NEJMp1601013

[6] Krishna P V, Jyothirmayi V, Madhusudhana RK. Human health risk assessment of heavy metal accumulation through fish consumption. India Int. Res. J. Public Environ. Health 2015: 1 5: 121-125

[7] Muthumareeswaran MR, Alhoshan M, Agarwal GP Ultrafiltration membrane for effective removal of chromium ions from potable water. Sci. Rep. 2017; 71: 1-38. https://doi.org/10.1038/srep41423

[8] Jiwan S, Kalamdhad SA. Effects of Heavy Metals on Soil, Plants, Human Health and Aquatic Life. Int. J. Res. Chem. Environ. 2011; 12: 15-21.

[9] Alluri HK, Ronda SR, Settalluri VS, Singh J, Suryanarayana V, Venkateshwar, P 2007 Biosorption: An eco-friendly alternative for heavy metal removal J Biotechnol, 6, 29242931.

https://doi.org/10.5897/AJB2007.000-2461

[10] Aroua MK, Zuki FM, Sulaiman NM. Removal of chromium ions from aqueous solutions by polymer-enhanced ultrafiltration. J. Hazard. Mater. 2007; 1473: 752-758. https://doi.org/10.1016/j.jhazmat.2007.01.120

[11] Wang, Lawrence K, Hung, Yung-Tse, Shammas, Nazih K. Handbook of Environmental Engineering. Physico Chemical Treatment Processes. 1st ed. Humana Press; 2005.

[12] Brbooti DM, Abid BA, Al-Shuwaiki NM. Removal of Heavy Metals Using Chemicals Precipitation. Eng. and Techn. J. 2011; 29: 595-612.

[13] Neculita CM, Zagury GJ, Bussière B. Passive Treatment of Acid Mine Drainage in Bioreactors using Sulfate-Reducing Bacteria. J. Environ. Qual. 2007; 361: 1-16. https://doi.org/10.2134/jeq2006.0066

[14] Tetteh EK, Rathilal S. Application of Organic Coagulants in Water and Wastewater Treatment Organic Polymers. Intech Open 2019 
[15] Kurniawan TA, Chan GY, Lo WH, Babel S. Physico-chemical treatment techniques for wastewater laden with heavy metals. Chemical Engineering Journal 2006; 1181-2: 83-98. https://doi.org/10.1016/j.cej.2006.01.015

[16] Taylor P, Islamoglu S, Yilmaz L, Ozbelge HO. Development of a Precipitation Based Separation Scheme for Selective Removal and Recovery of Heavy Metals from Cadmium Rich Electroplating Industry Effluents. Sep. Sci. Technol. 2014; 4115: 3367-3385. https://doi.org/10.1080/01496390600851665

[17] Bhattacharyya D, Jumawan AB, Grieves RB. Separation of Toxic Heavy Metals by Sulfide Precipitation. Sep. Sci. Technol. 1979; 145: 441-452. https://doi.org/10.1080/01496397908058096

[18] Pushpalatha M. Electro- Fenton Process for wastewater treatment A Review. Int. J. Advan. Res. 2017; 3: 439-451.

[19] Ghosh P, Samanta AN, Ray S. Reduction of COD and removal of $\mathrm{Zn} 2+$ from rayon industry wastewater by combined electro-Fenton treatment and chemical precipitation. Desalination 2011; 2661-3, 213-217. https://doi.org/10.1016/j.desal.2010.08.029

[20] Matlock MM, Henke KR, Atwood DA. Effectiveness of commercial reagents for heavy metal removal from water with new insights for future chelate designs. J. Hazard. Mater. 2002; 92: 129-142. https://doi.org/10.1016/S0304-3894(01)00389-2

[21] Azimi A, Azari A, Rezakazemi M, Ansarpour M. Removal of Heavy Metals from Industrial Wastewaters: A Review. Chem. Bio. Eng. Rev. 2017; 41: 37-59. https://doi.org/10.1002/cben.201600010

[22] Papadopoulos A, Fatta D, Parperis K, Mentzis A, Haralambous KJ, Loizidou M. Nickel uptake from a wastewater stream produced in a metal finishing industry by combination of ion-exchange and precipitation methods. Sep. Purif. Technol. 2004; 393: 181-188.

https://doi.org/10.1016/j.seppur.2003.10.010

[23] Mabel VM, Raymundo LP, Callejas RG, Blanca EJN, Cisneros Pedro JJ, Alvarez. Heavy Metal Removal with Mexican Clinoptilolite: Multi-Component. Ionic Exchange 2000; 35: 337-378

https://doi.org/10.1016/S0043-1354(00)00270-0

[24] Naushad M, ALOthman ZA, Awual MR, Alam MM, Eldesoky GE. Adsorption kinetics, isotherms, and thermodynamic studies for the adsorption of $\mathrm{Pb} 2+$ and $\mathrm{Hg} 2+$ metal ions from aqueous medium using TilV iodovanadate cation exchanger. lonics 2015; 218:2237-2245. https://doi.org/10.1007/s11581-015-1401-7

[25] Barakat MA. New trends in removing heavy metals from industrial wastewater. Arabian J. Chem. 2011; 4: 361-377. https://doi.org/10.1016/j.arabjc.2010.07.019

[26] Lakherwal D. Adsorption of Heavy Metals: A Review. Int. J. Environ. Res. Development 2014; 4: 41-48.

[27] Sprynskyy M, Buszewski B, Terzyk AP, Namies'nik J. Study of the selection mechanism of heavy metal $\mathrm{Pb} 2+, \mathrm{Cu} 2+$, $\mathrm{Ni2}+$, and $\mathrm{Cd} 2+$ adsorption on clinoptilolite. J. Colloid. Interface Sci. 2006; 3041: 21-28. https://doi.org/10.1016/j.jcis.2006.07.068

[28] Gunatilake SK. Methods of Removing Heavy Metals from Industrial Wastewater. J. Multidiscip. Eng. Sci. Stud. 2015; 11: $12-18$.

[29] Lata S, Singh PK, Samadder SR. Regeneration of adsorbents and recovery of heavy metals: a review. Int. J. Environ. Sci. Technol. 2015; 124: 1461-1478. https://doi.org/10.1007/s13762-014-0714-9

[30] Ngah WSW, Hanafiah MAKM. Removal of heavy metal ions from wastewater by chemically modified plant wastes as adsorbents: A review. Bioresour. Technol. 2008; 9910: 39353948.

https://doi.org/10.1016/j.biortech.2007.06.011
[31] Ahmadijokani F, Tajahmadi S, Bahi A, Molavi H, Rezakazemi M, Ko F, Aminabhavi TM, Arjmand M. Chemosphere Ethylenediamine-functionalized Zr-based MOF for efficient removal of heavy metal ions from water. Chemosphere 2021; 264: 128466

https://doi.org/10.1016/j.chemosphere.2020.128466

[32] Insanullah Abbas A, Al-Amer AM, Laoui T, Al-Marri MJ, Nasser MS, Khraisheh, M, Atieh MA. 2016; Heavy metal removal from aqueous solution by advanced carbon nanotubes: Critical review of adsorption applications. Sep. Purif. Technol. 2006; 157: 141-161. https://doi.org/10.1016/j.seppur.2015.11.039

[33] Kumar V, Katyal D, Nayak S. Removal of heavy metals and radionuclides from water using nanomaterials : current scenario and future prospects. 2020. https://doi.org/10.1007/s11356-020-10348-4

[34] Tsekova K, Todorova D, Dencheva V, Ganeva S. Biosorption of copper II and cadmium II from aqueous solutions by free and immobilized biomass of Aspergillus niger. Biores. Technol. 2010; 101: 1727-1731. https://doi.org/10.1016/j.biortech.2009.10.012

[35] Abbas SH, Ismail IM, Mostafa TM, Sulaymon AH Biosorption of heavymetals: a review J Chem Sci Technol 1995; 3: 235250. https://doi.org/10.1021/bp00033a001

[36] Chebil L, Chouba L. Biosorption of $\mathrm{Cu} 2 \mathrm{p}$ and $\mathrm{Zn} 2 \mathrm{p}$ from aqueous solutions by dried marine green macroalga Chaetomorphalinum. J. Environ. Manage. 2009; 90: 34853489.

https://doi.org/10.1016/j.jenvman.2009.06.001

[37] Kakavandi B, Kalantary RR, Jafari AJ, Nasseri S, Ameri A Esrafili A, Azari A. Pbll Adsorption Onto a Magnetic Composite of Activated Carbon and Superparamagnetic Fe3O4Nanoparticles: Experimental and Modeling Study CLEAN - Soil, Air, Water. 438: 1157-1166. https://doi.org/10.1002/clen.201400568

[38] Joseph L, Jun B, Flora JRV, Min C, Yoon Y. Chemosphere Removal of heavy metals from water sources in the developing world using low-cost materials : A review. Chemosphere 2019; 229: 142-159. https://doi.org/10.1016/j.chemosphere.2019.04.198

[39] Shakoor MB, Ali S, Rizwan M, Abbas F, Bibi I, Riaz M, Khali U, Niazi NK, Rinklebe J. A review of biochar-based sorbents for separation of heavy metals from water. International Journal of Phytoremediation 2019; 1-16. https://doi.org/10.1080/15226514.2019.1647405

[40] Pang F M, Teng SP, Teng TT, Omar AM. Heavy Metals Removal by Hydroxide Precipitation and CoagulationFlocculation Methods from Aqueous Solutions. Water Qual. Res. J. 2009; 442: 174-182. https://doi.org/10.2166/wari.2009.019

[41] Al-Zoubi H, Ibrahim KA, Abu-Sbeih, KA. Removal of heavy metals from wastewater by economical polymeric collectors using dissolved air flotation process. J. Water Process Eng 2015; 8: 19-27.

https://doi.org/10.1016/j.jwpe.2015.08.002

[42] Tran T, Chiu K, Lin C, Leu H. ScienceDirect Electrochemical treatment of wastewater: Selectivity of the heavy metals removal process. Int. J. Hydrogen Energy 2017: 2-9.

[43] Bazrafshan E, Mohammadi L, Ansari-Moghaddam A, Mahvi $\mathrm{AH}$. Heavy metals removal from aqueous environments by electrocoagulation process- a systematic review. J. Environ. Health Sci. Eng. 2015; 131: 1-16. https://doi.org/10.1186/s40201-015-0233-8

[44] Agarwal IC, Rochon AM, Gesser HD, Sparling AB Electrodeposition of six heavy metals on reticulated vitreous carbon electrode. Water Res. 1984; 18: 227-232. https://doi.org/10.1016/0043-1354(84)90073-3 
[45] Selim KA, Hosiny FI, Khalek MAAE, Osama I. Kinetics and Thermodynamics of Some Heavy Metals Removal from Industrial Effluents Through Electro-Flotation Process. Colloid. Surf. Sci. 2017; 2: 47-53.

[46] Bakalár T, Búgel M, Gajdošová L. Heavy metal removal using reverse osmosis. Acta. Montan. Slovaca. 2009; 14: 250-253.

[47] Ozaki H, Sharmab K, Saktaywirf W. Performance of an ultralow- pressure reverse osmosis membrane ULPROM for separating heavy metal: effects of interference parameters. Desal. 2002; 144: 287-294. https://doi.org/10.1016/S0011-9164(02)00329-6

[48] Ipek U. Removal of Nill and Znll from an aqueous solution by reverse osmosis. Desal. 2005; 1742: 161-169. https://doi.org/10.1016/j.desal.2004.09.009

[49] Mohammadi T, Razmi A, Sadrzadeh M. Effect of operating parameters on $\mathrm{Pb} 2+$ separation from wastewater using electrodialysis. Desal. 2004; 167: 379-385. https://doi.org/10.1016/j.desal.2004.06.150

[50] Porter MC. Handbook of Industrial Membrane Technology. 1st ed. NOYES Publications; 1988

[51] Mulder M. Basic Principles of Membrane Technology. 2nd ed. Kluwer Academic Publishers; 1997. https://doi.org/10.1007/978-94-009-1766-8

[52] Bruggen BV, Koninckx A, Vandecasteele C. Separation of monovalent and divalent ions from aqueous solution by electrodialysis and nanofiltration. Water Research 2004; 385: 1347-1353.

https://doi.org/10.1016/j.watres.2003.11.008

[53] Zhu WP, Gao J, Sun SP, Zhang S, Chung TS. Polyamidoamine dendrimer PAMAM grafted on thin film composite TFC nanofiltration NF hollow fiber membranes for heavy metal removal. J. Membr. Sci. 2015; 487: 117-126. https://doi.org/10.1016/j.memsci.2015.03.033

[54] Murthy ZVP, Chaudhari LB. Separation of binary heavy metals from aqueous solutions by nanofiltration and characterization of the membrane using Spiegler-Kedem model. Chem. Eng. J. 2009; 1501: 181-187. https://doi.org/10.1016/j.cej.2008.12.023

[55] Luque S, Alvarez JR. Recovery of heavy metals from metal industry waste waters by chemical precipitation and nanofiltration Recovery of heavy metals from metal industry waste waters by chemical precipitation and nanofiltration. Desal. 2006; 742-744. https://doi.org/10.1016/j.desal.2006.03.498

[56] Mohammad AW, Teow Y H, Ang WL, Chung YT, OatleyRadcliffe DL, Hilal N. Nanofiltration membranes review: Recent advances and future prospects. Desal. 2015; 356: 226-254. https://doi.org/10.1016/j.desal.2014.10.043

[57] Iqbal J, Kim HJ, Yang JS, Baek K, Yang JW. Removal of arsenic from groundwater by micellar-enhanced ultrafiltration MEUF. Chemosphere 2007; 66: 970-976. https://doi.org/10.1016/j.chemosphere.2006.06.005

[58] Kim H, Baek K, Lee J, Iqbal J, Yang JW. Comparison of separation methods of heavy metal from surfactant micellar solutions for the recovery of surfactant. Desal. 2006; 191: 186-192.

https://doi.org/10.1016/..desal.2005.09.013

[59] Crini G, Morin-Crini N, Fatin-Rouge N, Déon S, Fievet P. Metal removal from aqueous media by polymer-assisted ultrafiltration with chitosan. Arabian. J. Chem. 2017; 10: S3826-S3839. https://doi.org/10.1016/j.arabjc.2014.05.020

[60] Labanda J, Khaidar MS, Sabaté J, Llorens J. Study of Cr-III desorption process from a water-soluble polymer by ultrafiltration. Desalination 2011; 281: 165-171. https://doi.org/10.1016/j.desal.2011.07.054
[61] Borbely G, Nagy E. Removal of zinc and nickel ions by complexation membrane filtration Process from industrial wastewater. Desalination 2007; 240: 218-226. https://doi.org/10.1016/j.desal.2007.11.073

[62] Amira AA, Doan H, Lohi A, Cheng C. Morphology Control of Polysulfone Membranes in Filtration Processes : a Critical Review. Chem. Bio. Eng. Rev. 2015; 2: 22-43. https://doi.org/10.1002/cben.201400030

[63] Molinari R, Argurio P, Poerio T, Gullone G. Selective separation of copperll and nickelll from aqueous systems by polymer assisted ultrafiltration. Desal. 2006; 728-730. https://doi.org/10.1016/j.desal.2006.03.503

[64] Rezaee R, Nasseri S, Mahvi AH, Nabizadeh R, Mousavi SA, Rashidi A, Jafari A, Nazmara S. Fabrication and characterization of a polysulfone-graphene oxide nanocomposite membrane for arsenate rejection from water. J. Environ. Health Sci. Eng. 2015; 131: 1-11. https://doi.org/10.1186/s40201-015-0217-8

[65] Hernández-aguirre $O A$, Núñez-pineda A, Tapia-tapia $M$, María R, Espinosa G. Surface Modification of Polypropylene Membrane Using Biopolymers with Potential Applications for Metal Ion Removal. 2016. https://doi.org/10.1155/2016/2742013

[66] Qi Y, Zhu L, Shen X, Sotto A, Gao C, Shen J. Polythyleneimine-modi fi ed original positive charged nano fi Itration membrane : Removal of heavy metal ions and dyes. Separation and Purification Technology 2019; 222: 117-124. https://doi.org/10.1016/j.seppur.2019.03.083

[67] Ma Y, Shi F, Ma J, Wu M, Zhang J, Gao C. Effect of PEG additive on the morphology and performance of polysulfone ultrafiltration membranes. Desal, 2011; 272: 51-58. https://doi.org/10.1016/j.desal.2010.12.054

[68] Hamzah S, Ariffin MM, Ali A, Mohammad AW. High performance of polysulfone ultrafiltration membrane: Effect of polymer concentration. J. Eng. Appl. Sci. 2014; 912: 25432550.

[69] Azevedo R, Rodriguez E. Phytotoxicity of Mercury in Plants: A Review. J. Botany 2012; 1-6 https://doi.org/10.1155/2012/848614

[70] Shanker AK, Carlos C, Herminia L, Avudainayagam S. Chromium Toxicity in plants. Environ. Int. 2008; 315: 739-53. https://doi.org/10.1016/j.envint.2005.02.003

[71] Kanwal R, Fiza F, Iqra W, Muhammed SHA. Prevalence of exposure of heavy metals and their impact on health consequences. J. Cellular Biochem. 2017; 157-184. https://doi.org/10.1002/jcb.26234

[72] Finnegan PM, Chen W. Arsenic toxicity: The effects on plant metabolism. Frontiers in Physiology 2012; 3 JUN: 1-30. https://doi.org/10.3389/fphys.2012.00182

[73] Balasubramanian K. An effective technique for removal and recovery of uranium-vi from aqueous solution using cellulose-camphor soot nanofibers. RSC. Adv. 2014; 4: 27691-27701.

https://doi.org/10.1039/C4RA01751J

[74] Gough LP, Shacklette HT, Case AA. Element Concentrations Toxic to Plants, Animals, and Man. Geol. Surv. Bull. 1979; 180.

[75] Pour P, Takassi M, Hamoule T. Removal of Aluminum from Water and Industrial Waste Water. Orient. J. Chem. 2014; 303: 1365-1369. https://doi.org/10.13005/ojc/300356

[76] Sundar S, Chakravarty J. Antimony Toxicity. Int. J. Environ. Res. Public Health 2010; 712: 4267-4277. https://doi.org/10.3390/ijerph7124267

[77] Asakura K, Satoh H, Chiba M, Okamoto M, Serizawa K, Nakano M, Omae K. Genotoxicity Studies of Heavy Metals: Lead, Bismuth, Indium, Silver and Antimony. J. Occup. Health 2009; 516: 498-512. https://doi.org/10.1539/joh.L9080 
[78] Thomas M, Białecka B, Zdebik D. Removal of copper, nickel and tin from model and real industrial wastewater using sodium trithiocarbonate, The negative impact of complexing compounds. Archives Environ. Protect. 2018; 44: 33-47.
[79] Sobrova P, Zehnalek J, Adam V, Beklova M, Kizek R. The effects on soil/water/plant/animal systems by platinum group elements. Eur. J. Chem 2012; 105: 1369-1382.

https://doi.org/10.2478/s11532-012-0073-7

Received on 22-01-2021

Accepted on 28-02-2021

Published on 07-03-2021

http://dx.doi.org/10.15379/2410-1869.2021.08.01.01

(c) 2021 Mahajan-Tatpate et al.; Licensee Cosmos Scholars Publishing House.

This is an open access article licensed under the terms of the Creative Commons Attribution Non-Commercial License

(http://creativecommons.org/licenses/by-nc/3.0/), which permits unrestricted, non-commercial use, distribution and reproduction in any medium, provided the work is properly cited. 